\title{
DISCRETIONARY MEASURES AND AUTOMATIC STABILIZERS IN THE CROATIAN FISCAL POLICY
}

\begin{abstract}
The role of fiscal policy as a tool to stabilize business cycle fluctuations has been at the center of recent public debates. If governments allow automatic fiscal stabilizers to work fully in a downswing but fail to resist the temptation to spend cyclical revenue increases during an upswing, the stabilizers may lead to bias toward budget positions. This paper assesses to what extent some items of the Croatian central government budget operate to smooth the business cycle. For disentangling automatic stabilizers from discretionary measures, this research relies on the European Commission methodology. Results show that the structural budget balance was on average 1.74\% of GDP in deficit in the period between 1995 and 2009. Automatic stabilisation in Croatia is relatively weak and supplemented by discretionary measures, which led to "destabilizing" the economic activity in a pro-cyclical manner in Croatia in several observed periods.
\end{abstract}

Key words: fiscal policy, automatic stabilizers, discretionary measures, cyclically adjusted budget balance, Croatia

\section{INTRODUCTION}

The public economics literature has shown that economic cycles have important shortterm effects on public finance. To look at the cyclical properties of the overall budget balance, it is common to split it in two components: the cyclical balance and the cyclically adjusted (or structural) balance (Gali and Perotti, 2003). Variations in the cyclical balance are out of the control of fiscal authorities and show the work of automatic stabilizers, while changes in the cyclically adjusted budget balance are generally interpreted as resulting from discretionary actions taken by policy makers. Moreover, the latter can be used to provide an early warning of the need for budgetary adjustment and changes in the future direction of policy (Chourquai, Hagemann and Sartor, 1990).

Recently, the cyclically adjusted budget balance became important as an indicator for surveillance of fiscal discipline, especially in the context of the European Monetary Union and the related Stability and Growth Pact (SGP). According to the latter, the cyclically adjusted budget balance is calculated to assess whether the prevailing fiscal situation in individual member states is sufficient to adhere to the requirements of the Pact. Based on these calculations the European Commission is able to determine whether the member states' position is strong enough to guarantee that the actual budget deficit does not exceed the threshold of three percent of GDP during a cyclical downturn (European Commission, 2006). In this way the European Commission accents that fiscal stabilization should be primarily left to automatic stabilizers, while discretionary fiscal policy should be an exemption (Buti and van den Noord, 2004).

\footnotetext{
* Juraj Dobrila University, Department for economics and tourism “Dr. Mijo Mirković”, Preradovićeva 1, 52100 Pula, Croatia. Email: agrdovic@efpu.hr
} 
The main issue of this paper is to discuss the role and impact of fiscal policy in Croatia by disentangling the budget balance in its cyclical and structural (i.e. cyclically adjusted) component. The purpose of calculating cyclical components of the budget balance is to obtain a clearer picture of the impact of cyclical variations in economic activity on the Croatian government budget and to use this information as an indicator of the degree of economic stabilization resulting from «automatic» fiscal policy. Emphasizing the structural component of the budget balance along with its changes for Croatia aims at identifying the fiscal policy stance in contraction and expansion times in Croatia. Still, although a similar research is done by Švaljek, Vizek and Mervar (2010) using the methodology developed by the European System of Central Banks, this paper tries to accents how would the European Commission and European Council evaluate the Croatian fiscal policy in the context of the SGP (i.e. in the framework of the so called preventive and dissuasive arm) and enlighten eventual fiscal policy rules. Moreover, the motivation for this paper lies also in assessing the fiscal policy stance as well as the role, extent and strength of automatic stabilization in Croatia, which should be an important input for future empirical and theoretical research in economic policy on the Croatian case.

The rest of the paper is organized as follows. Section 2 presents a theoretical framework of fiscal policy's channels for macroeconomic stability and the reason why the cyclically adjusted budget balance became crucial for deriving policy conclusions. Section 3 is divided in three parts. The first part deals with some empirical facts about business cycles, budget balance and fiscal ratios in the case of Croatia. The second part shows the estimation results of the cyclical and structural component of the budget balance using the European Commission approach, while the third part questions the implications of the structural budget balance in managing public debt in a very intuitive manner. Section 4 considers some policy implications and recommendations while Section 5 is reserved for concluding remarks.

\section{THEORETICAL FRAMEWORK}

Fiscal policy can contribute to macroeconomic stability through three main channels. The first channel involves automatic stabilizers. They reflect the capability of the tax and public spending system to adjust over the business cycle without direct government intervention ${ }^{\mathrm{i}}$. Automatic stabilization occurs because tax revenues tend to be broadly proportional to national income and expenditure, whereas public spending reflects government commitments independent of the business cycle and unemployment benefits designed to support spending during downturns. The second channel embraces discretionary measures. Governments can deliberately change public spending and tax instruments to offset business cycle fluctuations. The third channel deals with the fact that the structure of tax and transfer system can be designed to maximize economic efficiency and thereby enhance the flexibility of the economy in the face of shocks.

Nominal figures of the actual budget balance reflect both, automatic stabilizers and discretionary measures. Therefore, they are not useful when trying to assess the positioning of underlying fiscal policy and possible structural imbalances, i.e. fiscal positions generated under the potential level of output.

In order to capture the cyclical properties of the actual budget balance it has to be divided in two components: the cyclical balance and the cyclically adjusted or structural balance (Gali and Perotti, 2003). The cyclical budget balance requires two inputs: (1) a measure of the cyclical position of the economy, generally estimated using the output gap and (2) a measure of the link between economic cycle and budget, generally outlined by the elasticity parameters that represent a percentage change in a budgetary item associated with a 
percentage change in the level of economic activity. Hence by construction, the cyclical balance is zero when the output gap is closed (i.e. actual output equals the trend level of output). Subtracting the cyclical balance from the actual budget balance provides the cyclically adjusted budget balance (or structural budget balance). The latter shows a hypothetical balance that would be observed if output was on potential or trend level. Changes in the cyclically adjusted budget balance are generally interpreted as discretionary actions taken by fiscal authorities, while the cyclical budget reflects the functioning of automatic stabilizers.

According to the OECD (Giorno, 1995) estimates of the structural balance help to "provide a clearer picture of government's underlying fiscal situation" and can be used "as a guide to fiscal policy analysis". Being that the fact, the cyclically adjusted budget balance started to play a crucial role for deriving concrete policy conclusions and different methodologies for its evaluation emerged, among which the most commonly used are those developed by international institutions such as the IMF, OECD, ECB and EC (for an overview of all approaches see Boije (2004)).

Given its raising popularity, measures of the cyclically adjusted balance started to reveal some shortcomings. A first set of shortcomings appeared in the late 1980s when Blanchard (1990) pointed out that the cyclically adjusted budget balance, along with its predecessor, the full employment surplusi ${ }^{i i}$, was used as «jack-of-all-trades». Although its original purpose was to tell what would be the balance if the economy was operating at full employment, the OECD relied on it as «index of discretionary changes in fiscal policy, index of sustainability, index of fiscal policy on the economy and as normative index» (Blanchard, 1990). A second set of shortcomings appeared when the cyclically adjusted budget balance started to be targeted for fiscal surveillance, mainly by the European Commission in context of the SGP ${ }^{\text {iii }}$. A fiscal surveillance based on such an indicator has to be taken with caution for several reasons. Larch and Salto (2005) point out that whenever potential output turned out to be lower or higher than assumed, observed changes in the cyclical budget balance were off the target even if budget plans were implemented accurately ${ }^{\text {iv }}$. Additionally, the assumption of constant tax elasticities may be acceptable as long as the variations in the tax content of economic growth remains small ${ }^{\mathrm{v}}$. Nevertheless, the revealed shortcomings during the EU fiscal surveillance were actually linked to a specific economic event. Therefore the European Commission did not abandon the cyclically adjusted budget balance, but strived to understand the reasons of the shortcomings and tried to look ways to improve the accuracy of the indicator $^{\mathrm{vi}}$ (Larch and Turrini, 2009). However, nowadays the main shortcoming of the structural budget balance is related to the estimation of potential output, which is taken as reference path when estimating balance measures (for potential output estimation methods see Boije (2004), Giorno et. al (1995) or Bouthevillain et al (2001)).

Moreover, empirical practice showed that targeting the cyclically adjusted, instead of the actual, budget balance results in a number of benefits. For instance, such targeting facilitates the implementation of counter-cyclical fiscal policy, leads to an increase in public saving during periods of strong growth while reducing government's needs for foreign financing and ensures financial stability of social policies and facilitates their long-term planning. Fiscal rules involving the cyclically adjusted budget balance are also considered to be important when monitoring public debt sustainability. 


\section{AUTOMATIC STABILIZERS VS. DISCRETIONARY MEASURES: CASE OF CROATIA}

This Section focuses on disentangling the cyclical and the structural component of the budget balance in the Croatian case and analyses their implications. As a rule, the measurement of the cyclically adjusted budget balance includes three steps. The first step involves the estimation of the potential output that could be obtained in the absence of cyclical fluctuations in the economy. The difference between the actual output and the estimated potential level of output results in the output gap. The second step takes into account the estimated output gap and budgetary revenues and expenditure elasticities in order to evaluate the sensitivity of budgetary items and reveal what would be their size (value) in a case of closed output gap. The correction for cyclical changes is important because the budget balance tends to deteriorate (improve) during recessions (expansions) as a result of automatic stabilizers. The third step consists of the estimation of the cyclically adjusted budget balance (or structural budget balance) by subtracting from the actual budget balance the cyclical budget balance.

The analysis in this paper is based on quarterly data for the period 1995:1 to 2009:4 (i.e. 60 observations) and the following two facts are important to be noticed.

First of all, empirical practice shows that the estimation of cyclically adjusted budget balance is usually based on general government data. This paper uses quarterly data at the central government level, mainly because quarterly data about total revenue and expenditures for the general government are not available for the period between 1995 and 2004. Nevertheless, this should not pose a limitation for this research principally for two reasons: firstly, in Croatia the central government carries all the discretionary policy actions and local governments have no «fiscal power» in this sense, and secondly, the share of local government in the general government is on average less than $10 \%$, so its omission should not significantly influence the estimation results ${ }^{\mathrm{vii}}$.

Secondly, in 2004 the government finance statistic in Croatia registered a structural break due to a methodological change in government accounting. Specifically, a switch from the Government Finance Statistics 1986 (GFSM 1986) to the Government Finance Statistics 2001 (GFSM 2001) methodology occurred. In order to have a more consistent series this research uses quarterly data on central government based on GFSM 1986 only. That is, data after the second quarter 2004 were reclassified from GFSM 2001 to GFSM 1986 (a broad overview of the reclassification method is presented in Appendix 1). Although the newer version of GFSM is more accurate, especially because it integrates acquisition and sale flows of nonfinancial and financial assets in government accounting, the lack of a detailed statistics on general government prior to year 2004 excluded the possibility to have a consistent series based on GFSM 2001.

\subsection{EMPIRICAL FRAMEWORK: OUTPUT GAP, BUDGET BALANCES AND FISCAL RATIOS}

In order to assess the cyclically adjusted budget balance the evaluation of the output gap, budget balances and fiscal ratios is needed. This research bases the estimation of output gaps on the Hodrick-Prescott filter ${ }^{\text {viii }}$. Such a filtering requires an appropriate selection of the smoothing parameter $\lambda$. When the estimation is derived from quarterly data, it is empirical practice to choose the smoothing parameter being 1600 as suggested by Hodrick and Prescott (1980) in their original work. The choice of the weight parameter $\lambda$ in this research is actually lower than the latter and follows the suggestion given by the ESCB (ECB) in the 
work of Bouthevillain et al (2001). After a detailed analysis of a «reasonable» length of the business cycle over which budgets should be balanced the ESCB (ECB) suggests a value of $\lambda=30$ for annual data and the value of $\boldsymbol{\lambda}=\mathbf{4 8 0}$ for quarterly data ${ }^{\text {ix }}$.

After the initial and highest contraction in the beginning of the $1990 \mathrm{~s}^{\mathrm{x}}$, output growth has been more stable in Croatia. The real GDP growth rate in the observed period resulted to be on average 3.44\%, reaching the lowest rate in $2009(-5.8 \%)$ as a spill over effect of the global recession. Figure 1 shows output growth rates and estimated output gaps in the period between 1995 and 2009.

Figure 1 Output gap (left scale) and real output growth rates (right scale) in Croatia in the period between 1995 and 2009

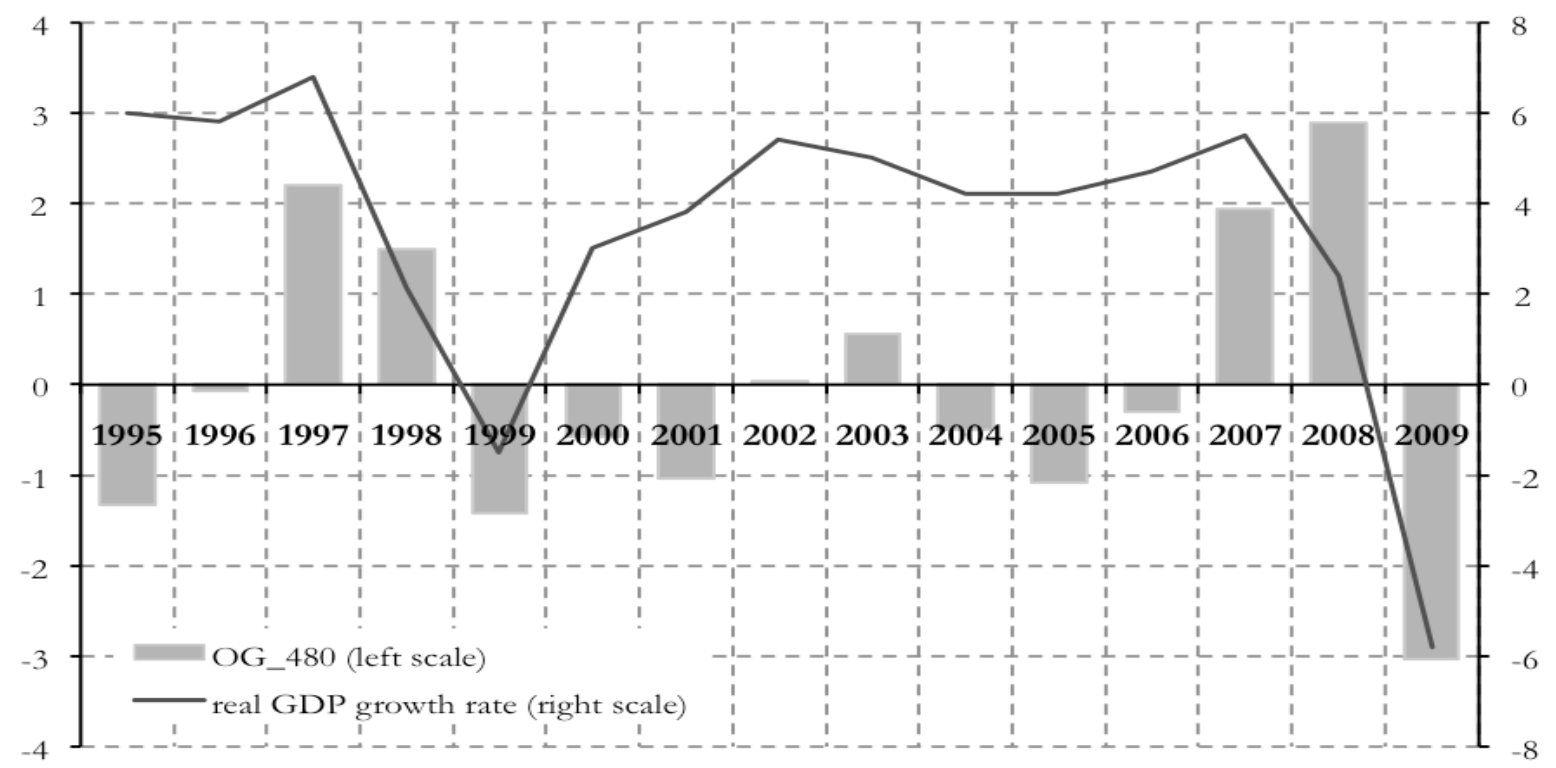

Source: Croatian Bureau of Statistics (2010); Author's calculation

When considering the relations between the output growth and the output gap it may be concluded that in the observed period Croatia faced twice phases of late contraction and twice of late expansions. The negative output gap and negative output growth rate were registered in 1999 and 2009, while a positive output gap along with positive growth rate was evidenced in 1997 and in the two-year period 2007-2008. Interesting to notice is that the early expansion phase in the period between 2000 and 2002 was not followed by a late expansion phase but by an early contraction phase in 2003, meaning that there was no boom (or prosperity) in the Croatian economy but just a recovery phase ${ }^{\mathrm{xi}}$.

In the observed period the central government budget balance was on average 3.8 billions kunas in deficit (Figure 2). Nominally speaking, the highest deficit is registered in 2009 (10.1 billions kunas), but still, when expressing the balance in per cent of gross domestic product the lowest deficit was recorded in 2000 (4.18\% GDP). 
Figure 2 Central government budget balance in millions HRK (left scale) and in percentage GDP (right scale) in Croatia in the period between 1995 and 2009

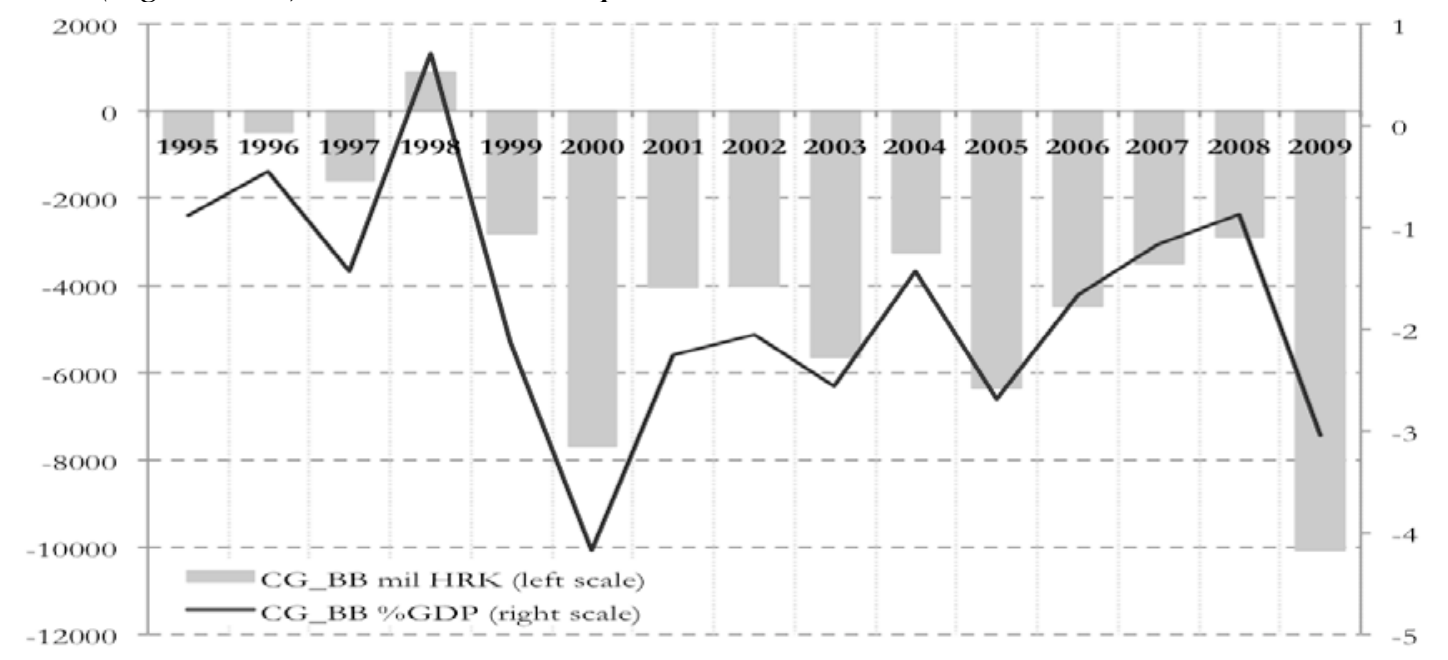

Note: Central government (CG) budget balance is expressed according to GFSM 1986 Source: Ministry of finance's Statistical Report (several issues); Author's calculation

The central government budget balance faced a deficit through the whole observed period fluctuating around $-1.75 \%$ of GDP, except in 1998 when the newly introduced value added tax (VAT) replaced the sales tax and lead to a rapid growth in budgetary revenues. From then on, VAT revenues became the most abundant tax revenue in Croatia, accounting on average $12.47 \%$ of GDP in the observed period.

Direct taxes add up to $6.06 \%$ GDP on average and have a small contribution to central government revenues. Interesting to notice is that the personal income tax (PIT) revenue decreased its financial importance during the observed period, while the corporate income tax (CIT) revenue moved in the opposite direction (Table 1). Lower PIT revenues are due to numerous changes in the personal income tax legislation, that included raising the level of personal allowance, widening and adding tax brackets, reducing tax rates and introducing deductions ${ }^{\mathrm{xii}}$. 
Table 1 Fiscal ratios in Croatia, percent GDP

\begin{tabular}{|c|c|c|c|c|c|c|c|c|c|}
\hline & $\begin{array}{c}199 \\
5\end{array}$ & $\begin{array}{c}199 \\
7\end{array}$ & $\begin{array}{c}199 \\
9\end{array}$ & $\begin{array}{c}200 \\
1\end{array}$ & $\begin{array}{c}200 \\
3\end{array}$ & $\begin{array}{c}200 \\
5\end{array}$ & $\begin{array}{c}200 \\
7\end{array}$ & 2009 & $\begin{array}{c}\text { Average } \\
95-09\end{array}$ \\
\hline $\begin{array}{l}\text { TOTAL } \\
\text { REVENUE }\end{array}$ & $\begin{array}{r}43.9 \\
6\end{array}$ & $\begin{array}{r}43.0 \\
2\end{array}$ & $\begin{array}{r}47.5 \\
4\end{array}$ & $\begin{array}{r}37.0 \\
9\end{array}$ & $\begin{array}{r}35.6 \\
7\end{array}$ & $\begin{array}{r}35.1 \\
5\end{array}$ & $\begin{array}{r}36.2 \\
6\end{array}$ & $\begin{array}{r}34.4 \\
1\end{array}$ & 38.89 \\
\hline Direct taxes & 6.82 & 6.86 & 6.99 & 4.72 & 5.04 & 5.02 & 6.74 & 5.96 & 6.06 \\
\hline $\begin{array}{l}\text { Personal income } \\
\text { tax }\end{array}$ & 5.80 & 5.41 & 5.32 & 3.69 & 3.69 & 3.52 & 3.94 & 3.13 & 4.38 \\
\hline $\begin{array}{l}\text { Corporate } \\
\text { income tax }\end{array}$ & 1.02 & 1.44 & 1.67 & 1.04 & 1.36 & 1.50 & 2.81 & 2.83 & 1.68 \\
\hline Indirect taxes & - & - & $\begin{array}{r}18.3 \\
0\end{array}$ & $\begin{array}{r}16.2 \\
2\end{array}$ & $\begin{array}{r}15.8 \\
2\end{array}$ & $\begin{array}{r}15.2 \\
2\end{array}$ & $\begin{array}{r}15.8 \\
7\end{array}$ & $\begin{array}{r}14.4 \\
2\end{array}$ & $16.22 *$ \\
\hline Value added tax & - & - & $\begin{array}{r}13.9 \\
7\end{array}$ & $\begin{array}{r}12.1 \\
9\end{array}$ & $\begin{array}{r}12.3 \\
8\end{array}$ & $\begin{array}{r}12.1 \\
4\end{array}$ & $\begin{array}{r}12.0 \\
1\end{array}$ & $\begin{array}{r}11.1 \\
2\end{array}$ & $12.47 *$ \\
\hline Excise & 5.04 & 4.33 & 4.33 & 4.02 & 3.44 & 3.08 & 3.86 & 3.30 & 3.95 \\
\hline $\begin{array}{l}\text { Social security } \\
\text { contributions }\end{array}$ & $\begin{array}{r}16.2 \\
5 \\
\end{array}$ & $\begin{array}{r}16.0 \\
1 \\
\end{array}$ & $\begin{array}{r}13.7 \\
6 \\
\end{array}$ & $\begin{array}{r}11.3 \\
4 \\
\end{array}$ & $\begin{array}{r}10.5 \\
3\end{array}$ & $\begin{array}{r}10.3 \\
8 \\
\end{array}$ & $\begin{array}{r}10.3 \\
4 \\
\end{array}$ & $\begin{array}{r}12.0 \\
4\end{array}$ & 12.36 \\
\hline $\begin{array}{l}\text { TOTAL } \\
\text { EXPENDITURE }\end{array}$ & $\begin{array}{r}44.8 \\
4\end{array}$ & $\begin{array}{r}44.4 \\
6\end{array}$ & $\begin{array}{r}49.6 \\
8\end{array}$ & $\begin{array}{r}39.3 \\
5\end{array}$ & $\begin{array}{r}38.2 \\
4\end{array}$ & $\begin{array}{r}37.8 \\
4\end{array}$ & $\begin{array}{r}37.4 \\
3\end{array}$ & $\begin{array}{r}37.4 \\
6\end{array}$ & 40.64 \\
\hline $\begin{array}{l}\text { Unemployment- } \\
\text { related } \\
\text { expenditure }\end{array}$ & 0.27 & 0.43 & 0.38 & 0.38 & 0.33 & 0.34 & 0.24 & 0.38 & 0.34 \\
\hline $\begin{array}{l}\text { BUDGET } \\
\text { BALANCE - CG }\end{array}$ & $\begin{array}{r}- \\
0.88\end{array}$ & 1.44 & 2.13 & 2.26 & $\begin{array}{r}- \\
2.57\end{array}$ & $\begin{array}{r}- \\
2.69\end{array}$ & $\begin{array}{r}- \\
1.17\end{array}$ & $\begin{array}{r}- \\
3.05\end{array}$ & -1.75 \\
\hline
\end{tabular}

Note: * The average value accounts for the period from 1998 until 2009

Central government (CG) budget balance is expressed according to GFSM 1986

Source: Ministry of finance's Statistical Report (several issues)

In the observed period total revenue amounted on average 38.89\% of GDP, while total expenditure $40.64 \%$ of GDP. When considering taxes only, Croatia has a relatively high level of indirect taxes measured in terms of GDP, which is usually a characteristic of developing (or emerging) countries, while developed countries' tax system rely mostly on revenue from direct taxation. Indirect tax revenues in Croatia on average amount to $16.22 \%$. The important role of indirect taxes among fiscal revenues may result in a greater influence of fluctuations in private consumption on the overall budget balance. 


\subsection{THE CYCLICALLY ADJUSTED BUDGET BALANCE}

As mentioned previously, a variety of approaches have been developed to decompose government revenue and expenditure into cyclical and structural components. This research is based on the European Commission approach.

At the Ecofin Council meeting of May 2004, the European Commission decided that for the estimation of the output gaps the production function constitutes the reference method when assessing the cyclically adjusted budget balance. Moreover, the Hodrick-Prescott filter is to be used when assessing the stability and convergence programme for the new member states (NMS-12) ${ }^{\mathrm{xiii}}$ and remains a backup method for old member states.

The European Commission estimates budgetary elasticities for different revenue and expenditure categories according to the approach developed by the OECD and outlined in Giorno et al. (1995), van den Noord (2000) and Girouard and Andre (2005). The revenue sensitivity is a weighted average of four revenue elasticities (i.e. PIT, CIT, social security contributions and indirect taxes), whereby different components are weighted by their respective share in total revenue ${ }^{\text {xiv }}$. The expenditure sensitivity takes only into account unemployment related expenditure, which are assumed to be the only expenditure that «automatically» reacts to cycle fluctuations. However, it is important to notice that in their recent research, Darby and Melitz (2008) show that social spending like health and retirement benefits schemes are more countercyclical than generally acknowledged.

The overall cyclical sensitivity of the budget to the economic cycle measured by the semi-elasticity of the budget balance (as \% GDP) with respect to the output gap for Croatia is shown in Table 2.

Table 2 Summary of elasticities and the overall budget sensitivity in Croatia

\begin{tabular}{cccccc}
\hline $\begin{array}{c}\text { Personal } \\
\text { income } \\
\text { tax }\end{array}$ & $\begin{array}{c}\text { Social } \\
\text { security } \\
\text { contributions }\end{array}$ & $\begin{array}{c}\text { Corporate } \\
\text { income tax }\end{array}$ & $\begin{array}{c}\text { Indirect } \\
\text { taxes }\end{array}$ & $\begin{array}{c}\text { Current } \\
\text { expenditur } \\
\text { e }\end{array}$ & $\begin{array}{c}\text { Overall budget } \\
\text { balance } \\
\text { elasticity }\end{array}$ \\
\hline 0.36 & 0.32 & 1.31 & 0.50 & -0.01 & $\mathbf{0 . 4 7}$ \\
\hline
\end{tabular}

Note: Estimations for the mentioned budgetary items is presented in Appendix 2 Source: Author's calculation

The overall output elasticity of income tax in Croatia is estimated to be $0.36 \%$ of $\mathrm{GDP}^{\mathrm{xv}}$. This result is lower than the same in OECD countries and EU member states, where amounts on average to $1.0 \%$. Such a result is due to a lower degree of progressivity in the personal income taxation $^{\text {xvi }}$ (OECD average 1.7\%, Euro area average 2,0\%, Croatia 1.2\%) and lower output elasticity of employment (OECD average $0.6 \%$, Croatia $0.2 \%$ ). The elasticity of social security contributions in Croatia is also below the EU and OECD average ${ }^{\text {xvii }}$.

The CIT elasticity is consistent with the OECD and Euro area average (1.5\% and $1.4 \%$ respectively). Although the corporate tax in Croatia is proportional (as in most countries), the elasticity above unity is due to the fact that profits are fairly elastic with respect to output (Girouard and Andre, 2005). Additionally, when interpreting this elasticity, it is important to have in mind the treatment of profits and losses, and the provisions for carrying losses forward in other tax years, which in Croatia accounts for most five years. Figure 3 shows the estimation of the cyclical and structural component along with the actual budget balance and output gap for Croatia between 1995 and 2009. 
Figure 3 Output gap (OG) and actual, cyclical and cyclically adjusted budget balance (ABB, $C B B$ and CABB respectively) in Croatia in the period between 1995 and 2009, percent GDP

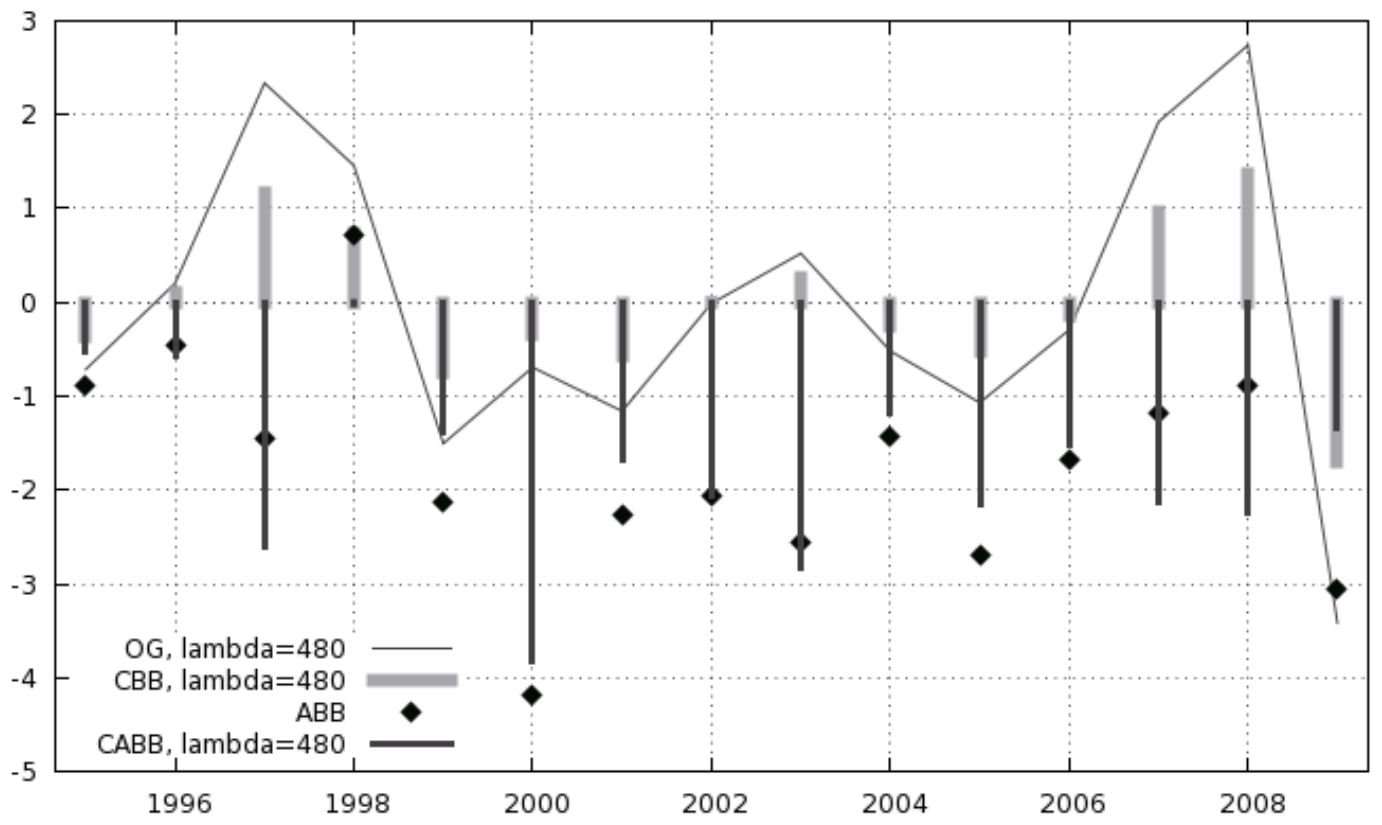

Source: Author's calculation

In the observed period the cyclical and cyclically adjusted budget balance were both on average in deficit by $0.01 \%$ and $1.74 \%$ of GDP, respectively. In the phases of late expansion and negative budget balance, the cyclical component registers a surplus, mainly because a high revenue's reaction to the increase in aggregate demand, which makes the actual budget deficit lower than the cyclically adjusted budget deficit.

When considering the size of the cyclical component, under a level of uncertainty it may be concluded that automatic stabilizers are not so strong in Croatia. This may be due to the fact that they may be constraint by the combination of low tax elasticities and a relatively low share of taxes in GDP that tends to reduce the responsiveness of revenues to demand shocks. Additionally, the role of expenditure stabilizers may be small because of the general absence of formal unemployment and social security compensation schemes.

Moreover, Debrun and Kapoor (2010) show that automatic stabilizers strongly contribute to output stability regardless of the type of economy (advanced or emerging), confirming the effectiveness of timely, predictable and symmetric fiscal impulses in stabilizing output. Deroose, Larch and Schaechter (2008) argue that «it is predominantly the differences in size of governments that impact how strong automatic stabilizers are» and stress that the government size reveals sufficient information on the magnitude of automatic stabilizers in different countries. In addition, van den Noord (2000) firstly, and Girouard and Andre (2005) afterwards, suggest that the most important factor in determining the cyclical sensitivity of the fiscal position is the size of the general government sector. The larger the share of government expenditure in domestic output, the greater the sensitivity of fiscal position to fluctuations in economic activity. The IMF (2009) uses for instance the aggregate tax to GDP ratio as a proxy for size of automatic stabilizers in G-20 countries. 
Figure 4. Overall budget sensitivity and the government size (proxied by government expenditure in upper panel and by government revenue in lower panel) in EU and Croatia
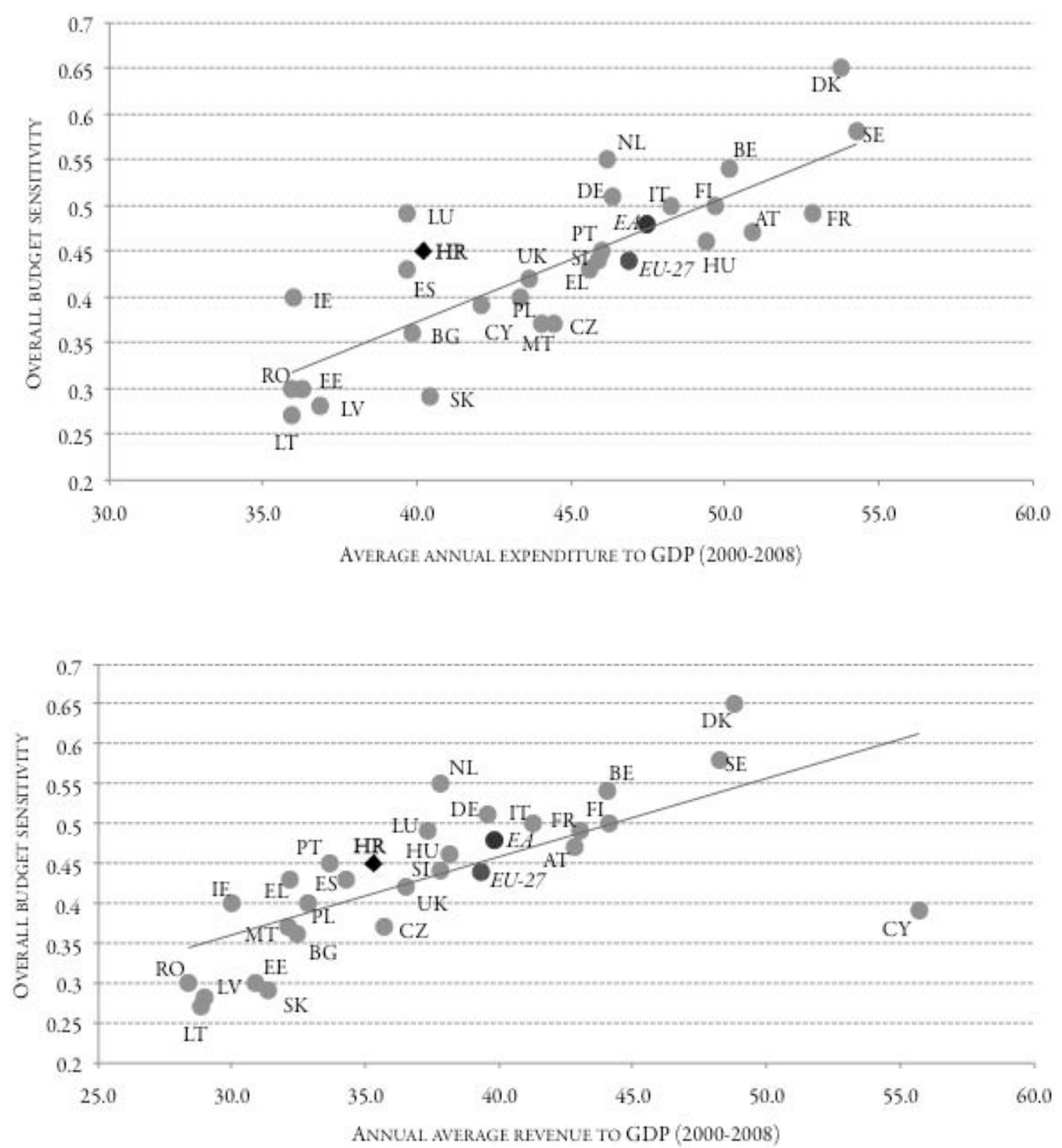

Note: The revenue category includes receipts from taxes and social security contributions.

Both revenue and expenditure data account for the general government.

Source: Eurostat (2010), Eller (2009), Ministry of finance's Yearbook (several issues), Author's calculation

With a correlation of 0.82 in case of annual expenditure (higher panel of Figure 4), and a correlation of 0.71 in case of annual revenue (lower panel of Figure 4), it may be concluded that government size is a good predictor for the amount of automatic stabilization.

Figure 4 shows that automatic stabilizers (proxied by the government size) are very heterogeneous within EU member states. Lower automatic stabilizers are evidenced in NMS12 and Croatia, although a lower average income (and wealth) registered in these countries should oppositely imply households to be more vulnerable to changes in aggregate demand. One reason of that could be that countries with lower per capita income tend to have smaller public sectors. From this perspective, weaker automatic stabilizers in Eastern and Southern European countries can potentially be an unintended side effect of the lower demand for government activity including redistribution. Another potential explanation could be the idea 
that more open economies have weaker automatic stabilizers because domestic demand spills over to other countries.

Eller (2009) shows that the automatic stabilization function of tax and expenditure systems is not as strongly pronounced in the NMS-12 as in the euro area. He showed that a $1 \%$ drop in GDP reduces total government revenues by around 1\%. As a consequence, the revenue (measured as percentages of GDP) remain almost constant over the business cycle in the euro area and in most of the developing European countries. The response of government expenditure to changes in output proved to be rather inelastic, because a 1\% decline in GDP drives up government spending by $0.10 \%$ in the NMS- 12 countries and $0.17 \%$ in the euro area. Auerbach (2002) shows that changes in the cyclical budget balance in the United States roughly offset one third of the output gap. The European Commission stresses that automatic stabilizers cushions changes in output between one tenth and one quarter depending on the degree of openness of countries and the structure of their public finance (European, Commission, 2008).

Oppositely to the automatic stabilizers, some countries decide to rely on discretionary actions when stabilizing the output or designing a more efficient fiscal system. As mentioned previously, changes in the cyclically adjusted budget balance can be (with caution) seen as discretionary fiscal policy. Positive changes in the cyclically adjusted balance are usually interpreted as indicator of restrictive fiscal policy, while negative changes are related to expansionary measures. So for instance, countercyclical (and stabilizing) fiscal policy is registered when during a negative output gap fiscal authorities implement expansionary discretionary measures (showed by a deterioration in the cyclically adjusted budget balance) or when, during a positive output gap restrictive measures are taken. Oppositely, procyclicality is evidenced. If changes in the cyclically adjusted balance are considered then it is possible to say that in the observed period fiscal policy in Croatia was pro- and countercyclical (Figure 5).

Figure 5 Changes in the cyclically adjusted budget balance (d_CABB) and output gap (OG) in Croatia for the period between 1995 and 2009, percent GDP

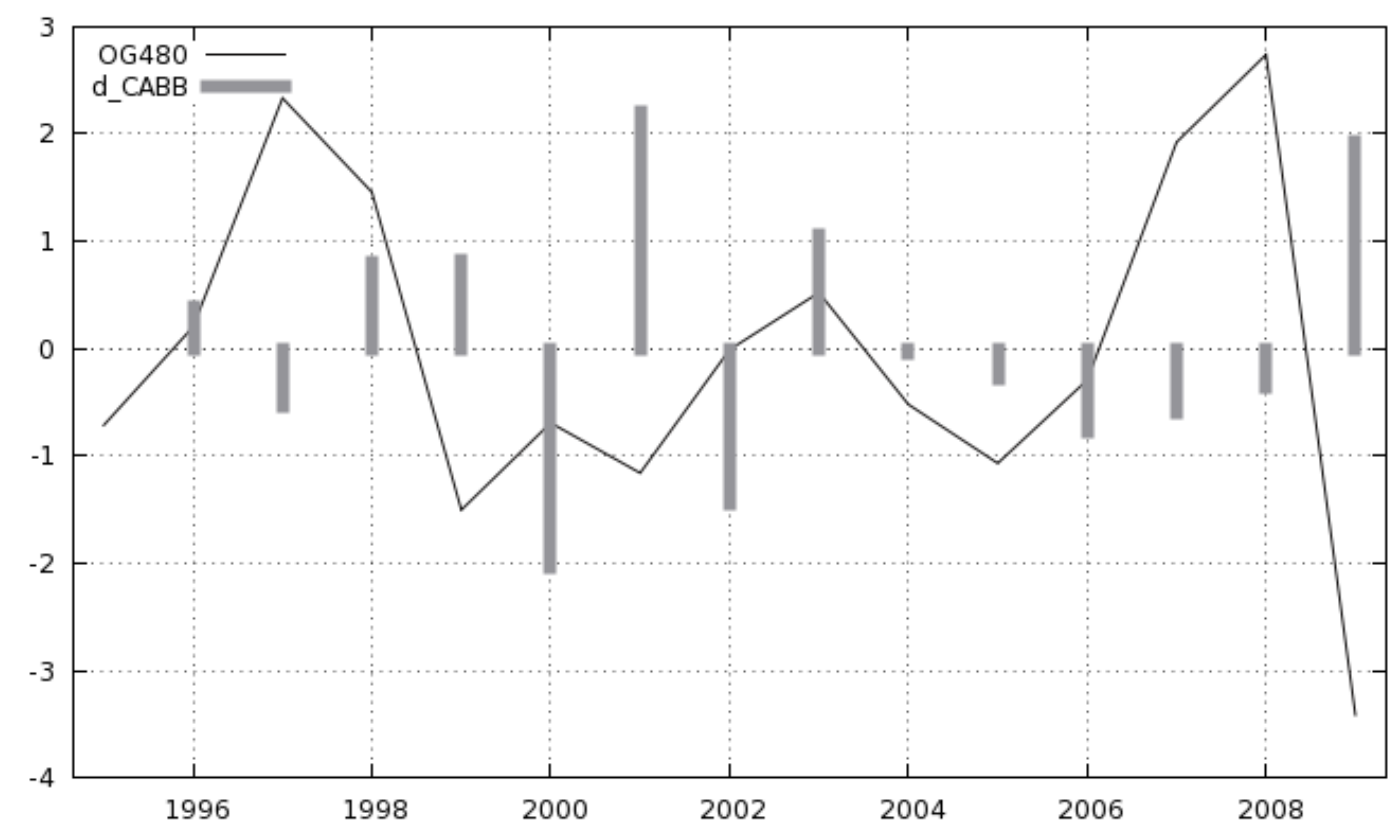

Source: Author's calculation 
Figure 5 shows that until year 2000, fiscal authorities carried out alternating counterand pro-cyclical discretionary policy ${ }^{\text {xviii }}$. Kaminsky et al (2004) emphasize that in emerging economies the often-registered pro-cyclicality of fiscal policy reflects a bias in discretionary fiscal policy, so enhancing automatic stabilizers would provide some counter-cyclical pushback. In the period between 2004 and 2008 Croatian fiscal policy was expansionary, but did not follow business cycle movements, i.e. until year 2006 expansionary fiscal policy was counter-cyclical (and thus stabilizing) due to contraction phase, but from 2006 onward the output gap results to be positive and thus expansionary fiscal policy becomes pro-cyclical. Although Švaljek, Vizek and Mervar (2009) using the ESCB approach show lower values of the cyclically adjusted budget balance as a consequence of higher values of budgetary revenue elasticity per tax category ${ }^{\mathrm{xix}}$, the estimated fiscal policy stance in their work reflects the same direction as in this research, except for year 1997.

Cimadomo (2005) estimated that the fiscal policy is neutral for small variations of the cyclically adjusted budget balance (between -0.2 and 0.2 percentage points). Being that the fact Figure 5 shows that Croatian fiscal policy may be considered neutral in 2004, when the change in cyclically adjusted budget balance respect to year 2003 amounted to $-0.04 \%$ of GDP. In all other periods changes were above the threshold set by Cimadomo (2005).

Although international institutions point that fiscal stabilization should be mainly performed by the work of automatic stabilizers, the debate on discretionary measures arose during the latest crisis (from mid 2008 on). Some countries have even been criticized for being unwilling to enact fiscal stimulus programs in order to stabilize demand (in particular Germany). One reaction to this criticism was to point the fact that automatic stabilizers (in Germany) are more important than in other countries, so that less discretionary actions are required. This may rise the question whether countries with weaker automatic stabilizers did take more discretionary actions. In order to "put" some light on this issue, the size of fiscal stimulus (i.e. change in the cyclically adjusted budget balance in 2009 against 2008) is related to the sensitivity coefficient (Figure 6).

Figure 6 Fiscal stimulus (as change in the structural budget balance in 2009 against 2008) and overall budget sensitivity in EU member states and Croatia, per cent GDP

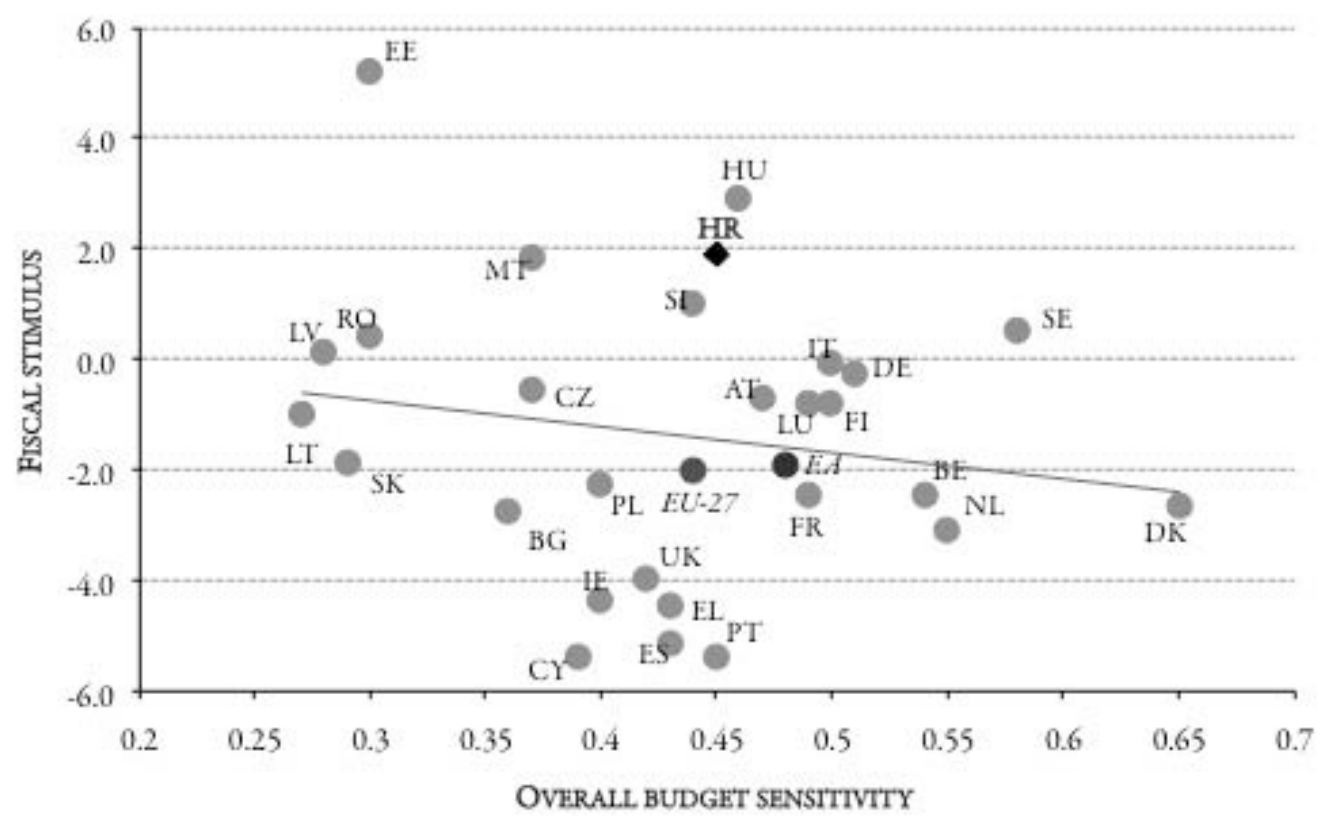

Source: European Commission (2009), Eller (2009) and Author’s calculation 
Figure 6 shows that the stabilization coefficients are largely uncorrelated with the size of fiscal stimulus $(-0.17)^{\mathrm{xx}}$, meaning that countries with lower automatic stabilizers have not hired more discretionary measures.

Generally, in case of contraction a fiscal stimulus refers to tax cuts and spending increase, in order to raise the overall state of the economy. Although therefore negative values of changes in the cyclically adjusted budget balance are expected (as sign of expansionary measures), a number of countries exercised restrictive fiscal policy in the beginning of the current crisis in 2009, amid which Croatia registers the second highest positive value. In the Croatian case, the government consciously refused to aknowledge that the global economic crises embraced Croatia prior to the first quarter in 2009, although its effects were registered even before. Additionally, instead of tax cuts, some new taxes ${ }^{\text {xxi }}$ were introduced and the VAT tax rate was raised by one percentage point, which obviously results more to be a fiscal “de-stimulus”.

Moreover, if the crisis is observed as a negative extarnality, it is obvious that due to the openness of an economy it may show spill-over effects on any economy related to the one of origin. If fiscal stimulus is considered as a positive externality, then some countries may show a free-rider behaviour and profit from spill-over effects of discretionary measures taken by another country, because the potential positive effects of fiscal stimulus are not limited to the country of origin. Dolls et al (2010) support this hypothesis and find a negative correlation $(-0.4)$ between discretionary measures and the openess coefficient (measured as the ratio of exports and imports to GDP) on the sample of $19 \mathrm{EU}$ member states and the US. In this context it is important to notice that, being a small open economy, Croatia is exposed to sporadic and often unpredictable events that affect its economic performance. Historically, events outside of Croatia's control have affected the welfare of its citizens because the country and the government have had to adjust their level of consumption and investment in line with economic conditions.

\section{PRACTICAL IMPLICATIONS AND POLICY RECOMMENDATIONS}

The important task that arises is to what extent the fluctuations in the budget balance should be automatic or discretionary?, or what is preferable: weak automatic stabilizers supplemented with discretionary fiscal policy or stronger automatic stabilizers? The latter has the advantage that it is more predictable in the sense that fiscal policy follows well-defined rules. Another advantage of «automatic» fiscal policy is that it avoids decision and implementation lags. Nevertheless, strong automatic stabilizers may turn out to be problematic when economy faces significant, permanent and negative shocks.

According to the European Commission's SGP, excessive deficits must be prevented and rapidly corrected. The reference value for government deficit is $3.0 \%$ of GDP, as set by the Maastricht Treaty convergence criteria. A deficit exceeding this threshold is considered exceptional only if it the result from an unusual event outside the control of the member state, or if it the result of a severe economic downturn (negative annual output growth over a prolonged period of very low annual growth).

The main logic of the SGP provision is to ensure sound budgetary policies on a permanent basis. The SGP lays down the obligation for Member States' commitments to adhere to the their medium-term budgetary objectives for their budgetary positions of "close to balance or in surplus, as defined under country-specific considerations. Adjusting to such positions allows Member States to deal with normal cyclical fluctuations without breaching the 3\% of GDP reference value for the government deficit. 
In March 2003 the Ecofin Council amended the SGP with a norm that should have a clear effect of improving counter-cyclicality during upturns (Cimadomo, 2005). It was recommended that member states with a deficit exceeding the "close to balance or surplus" requirement should improve their cyclically adjusted budget position by $0.5 \%$ of GDP. Cimadomo (2005) shows that the hypothesis of counter-cyclicality holds in downturn but in upturns a pro-cyclical bias is registered.

If considering a "hypothetical" Croatian case embraced by the SGP requirements, it is noticeable that in 2000 and 2009 the budget deficit did exceed the convergence criteria. Year 2009 may also be considered as exceptional due to the global crises spill-over effects. Still in year 2000 there was no particular downturn that caused the deficit exceeding the threshold of 3\% GDP, but parliamentarian elections and results in that year affected the openness of the economy. Therefore, that would be (a posteriori) the year when the Ecofin Council would implement the excessive deficit procedure and follow the given Ecofin measures. Important to stress is that in order to maintain sound fiscal positions provisions according to the SGP are made a priori, i.e. based on estimated movements of the budget balance. Additionally, if a member state exceeds the given deficit threshold in three consecutive years, the European Commission can impose a fine up to $0.5 \%$ of that country's GDP.

The Croatian fiscal system has been undergoing numerous structural changes from the beginning of the 1990s. Still, there are a lot of remaining "structural" goals to reach (as for instance social security reforms and fiscal decentralization) and discretion is probably going to remain dominant in the Croatian fiscal policy. Nevertheless, strengthening automatic stabilizers would pose a big challenge and ensure better fiscal performance ${ }^{\text {xxii }}$.

One way automatic stabilizers could be enhanced is by rising the shares of taxes collected from income-based taxes and thus increase their respective elasticities. In Croatia for instance the PIT could be made more progressive (increase the real wage elasticity of income tax per worker). The obtained elasticity of $1.21 \%$ is below the EU-27 average and the personal income taxation was based up to just four tax brackets until 2009, while in 2010 the tax brackets have been reduced to three. However, empirical practice shows that it would lead to a small increase in automatic stabilizers. Baunsgaard and Symansky (2009) showed that a shift in the composition of tax revenue by 5 percentage points from indirect taxes to PIT across G-20 countries would increase the automatic stabilization average by 0.05 percentage of GDP.

Another way of enlarging the role of automatic stabilizers could be by designing appropriate fiscal policy rules. Because fiscal rules can require discretionary policy changes that offset the operation of automatic stabilizers, the impact of fiscal rules will differ depending on the type of a rule (debt rule, deficit/balance rule, cyclically adjusted balance rule, expenditure rule, combination of any of those).

Targeting the cyclically adjusted balance instead of the nominal figures of actual budget balance would lead to financial sustainability of public policies, permitting a better long-term planning of social programmes and enhancing fiscal debt sustainability. The structural balance is intrinsically counter-cyclical in that it permits fiscal deficits when the economy is performing significantly below potential and surpluses when the opposite is registered. In this way it serves to attenuate both the economy's highs and lows ${ }^{\text {xiii }}$.

In the Croatian case for instance, in the observed period the total public debt was on average 69.2 billions kunas large, in which external debt accounts for 32 billions kunas. On average the Croatian government interest payments per year amount to 3.2 billions kunas. 
Figure 7 shows public debt and interest payment and cyclically adjusted budget balance in Croatia, all expressed as percentage of GDP.

Figure 7 Public debt (left scale), interest payments and cyclically adjusted budget balance (both left scale) in Croatia in the period between 1995 and 2009, per cent GDP

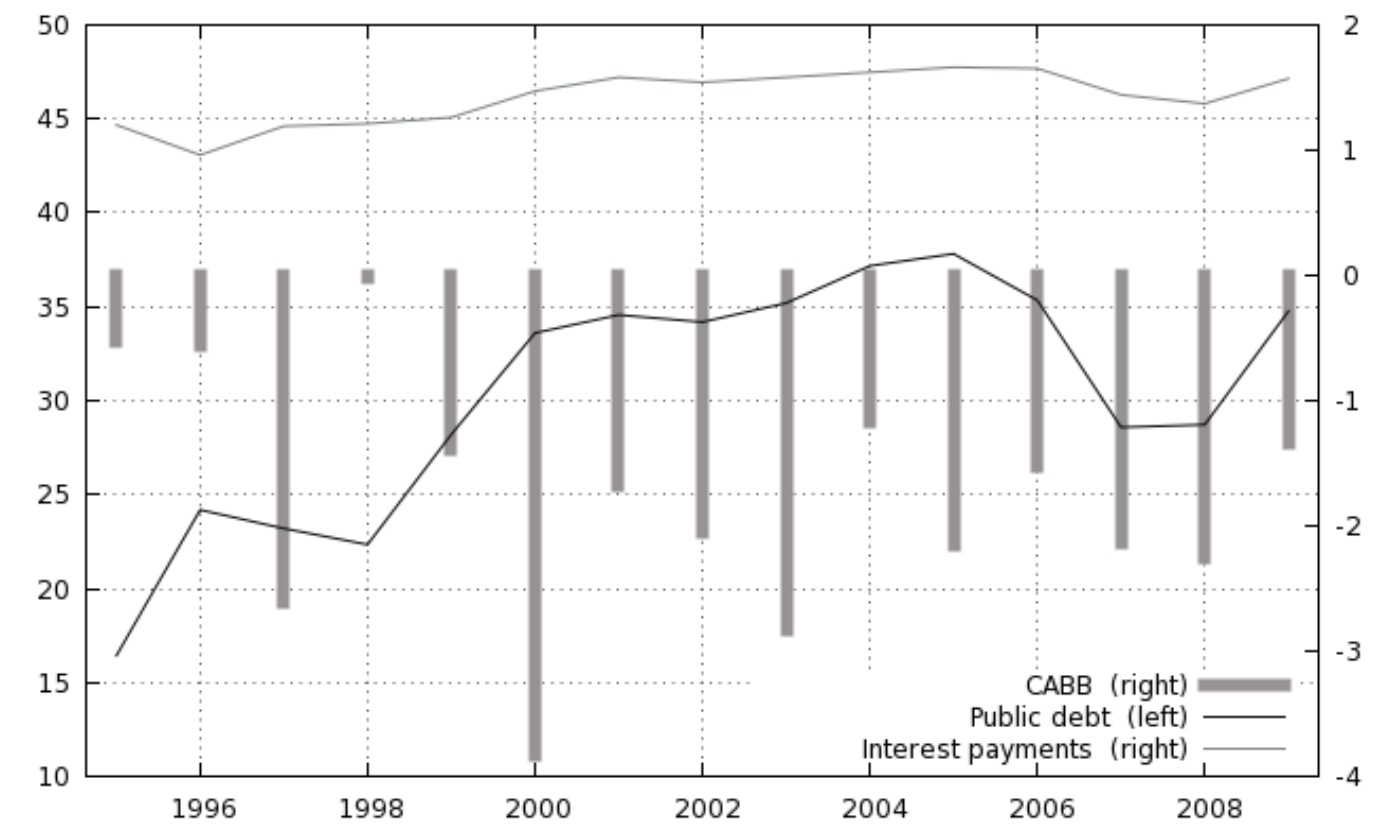

Source: Croatian National Bank (2010) and Author’s calculations

In the observed period public debt accounts on average to $30.3 \%$ of GDP, while interest payments amount to $1.42 \%$ of GDP on average. If the cyclically adjusted balance is considered the Croatian fiscal income was through the whole period negative. It can be noticed that the increase (decrease) in public debt follows the increase (decrease) of the structural budget balance. Targeting the cyclically adjusted budget balance (instead of the actual budget balance) could improve fiscal position and fiscal surveillance in Croatia and would help reduce pro-cyclicality and provide protection from external crises. Doing all that it would ensure a more balanced budget and therefore less need for public debt, which can allow for reallocation of public resources previously devoted to debt servicing. Savings from debt servicing can be used to finance social programmes and investments that stimulate economic growth. Moreover, Marcel et al (2003) show that conducting fiscal policy based on a cyclically adjusted balance target contribute to reduce the amplitude of economic cycles and ensures an adequate dynamics in the accumulation of assets.

Fiscal rules based on fiscal balance work against the stabilizers. If cyclical balance deteriorates, a fiscal balance rule (involving a ceiling of the balance in nominal figures or per cent GDP) requires offsetting discretionary tightening. Likewise, revenue rules, including linking expenditure to some revenues will also typically involve pro-cyclicality. Avoiding pro-cyclicality in a balanced budget rule is important in a fiscal rule design.

Solutions essentially involve balance-over-the-cycle rules or rules on structural balances. Balancing budgets over the business cycle ensures countercyclical fiscal policy by allowing the automatic stabilizers to operate freely, while discretionary countercyclical actions are also allowed. Additionally, such rules allow for better public debt management, 
servicing and sustainability, which lead to increase in public saving that can ensure financing social or other government programs.

\section{CONCLUSION}

The structure of the tax and expenditure system automatically stabilizes the business cycle in at least three ways (Eller, 2009). First, tax bases (such as income, profit or consumption) weaken/strengthen and thus the overall tax burden decreases/increases. Second, the public expenditure category with unemployment related benefits with the most pronounced countercyclical path, decreases as the number of unemployed go down. Third, many expenditure categories improve the stabilizing effects of fiscal policy as they show to be inactive in adjusting over the business cycle.

The overall responsiveness of the budget to cycle fluctuations in Croatia in the observed period is $0.47 \%$ and the cyclical budget balance was on average in deficit by $0.01 \%$ of GDP. Countercyclical (and stabilizing) periods in the Croatian economy are observed in the period between 1998 and 2000, and then in 2005, while fiscal authorities carried out procyclical discretionary policy during an expansion phase in 1997 and 2007, which even amplified the actual budget deficit. When comparing results these results with those in other countries, automatic stabilization in Croatia seems to be in line with the same in NMS-12 or CESEE countries, but below the average of developed countries.

Results shows that there is a lot of discretion in Croatia and that automatic stabilizers are weak and comparable to those in other emerging economies. Nevertheless, there is a global tendency that fiscal stabilization should mainly be performed by the work of automatic stabilizers rather than discretionary fiscal policy. But, important to notice is that institutions traditionally seen as symbol of fiscal austerity (such as the IMF and EC) have endorsed large fiscal stimulus packages during the severe downturn occurred in 2008 and 2009, and thus opted discretionary fiscal policy. The broad agreement on the need of fiscal stimulus is undoubtedly linked to the fact that the current global crisis is not a simple cyclical downturn but a deep recession.

Discretionary fiscal stimulus in OECD and EU countries has focused on 2009, with the 2010 amounts generally representing phased implementation of spending programs initiated in 2009 and the carryover of tax measures. In 2009 fiscal stimulus amounted to 1.8\% of GDP in G-20 and OECD countries, and 2.0\% of GDP in EU member states. Fiscal stimulus packages in the same year in Croatia are not registered. Fiscal authorities increased tax rates and introduced new taxes in 2008 and 2009 mainly because of lower budgetary revenues without considering their side effects especially when considering that the economy faces a late contraction phase. Additionally, in 2010 the government retracted most of the tax discounts involving personal and corporate income taxation.

A key factor that can explain differences in fiscal stimulus and the need for the latter across countries is the size of automatic stabilizers. Countries in which the automatic stabilizers are larger have generally less need to rely on discretionary stimulus. Still, the recent crises proved to be a deep recession so discretionary actions were crucial in countries with both weak and strong automatic stabilizers. Although Croatia has a relatively weak automatic stabilization, there is room for enlarging the role of automatic stabilizers.

Anyhow, once again it is worth mentioning that all the obtained results should be taken with caution because, first of all, the statistical method for estimating business cycles would require a longer series, which is unavailable for transition economies as in the Croatian 
case. Second, the cyclically adjusted budget balance highly depends on the quality of the government revenue and expenditure data; therefore an analysis based on general government data (reclassified according to GFSM 2001 for the period prior to 2004) would yield in more precise results. Third, the analysis assumes that the policy initiatives are undertaken as planned and not delayed. Still, pursuing some of the mentioned issues is intended in the future research.

${ }^{\mathrm{i}}$ For example, in boom times, governments collect more taxes and decrease the unemployment benefit support, which results in lowering private income to taxpayers and prevents the expansion in aggregate demand. Conversely, in recession times governments collect fewer taxes and increase unemployment benefit payments, which support private income and moderate the unfavourable movements in aggregate demand. For a deeper discussion on automatic stabilizers see van den Noord (2000) and Braconier and Holden (2001).

ii Amid the first to form and calculate an indicator, which would measure the level of the budget balance when the economy operates at a full employment level, was Brown in 1956 for the US economy and named it the full employment surplus (Brown, 1956). He showed that the assessment of fiscal policy in the US in the 1930s would have significantly changed if, instead of using the headline budget balance, it had been adjusted for the effect of unemployment.

iii The Stability and Growth Pact (SGP) is an agreement among EU member states that are part of the Euro zone to maintain the stability of the Economic and Monetary Union. The Pact was adopted in 1997 to maintain and enforce fiscal discipline in the Euro area. Member states adopting the euro have to meet the Maastricht convergence criteria and the Pact ensures the monitoring of the same criteria.

${ }^{\text {iv }}$ Although the IMF in its World Economic Outlook, the OECD in its Economic Outlook and, since recently, the EU in its European Economy regularly comment on fiscal positions in structural terms as measured by the cyclically adjusted balance, associating changes in structural deficit to discretionary policy interventions, in the early 2000s this practice gave rise to some disagreements in several EU member states when the cyclically adjusted budget balance was targeted for fiscal surveillance. Namely, observing a deterioration of the cyclically adjusted balance as expansionary fiscal stance, the European Commission blamed national fiscal authorities for deviations from budget plans on discretionary fiscal policy. In the same moment, national fiscal authorities maintained that the budget was implemented as firstly planned and that no increased discretionary spending was adopted. Such a disagreement pointed out one possible shortcoming of the cyclically adjusted balance because turned out to be related to two different points. On one side, national governments often overestimated their medium-term growth, while on the other side, the European Commission did not take into account that the decline in potential economic growth affect the cyclically adjusted balance.

${ }^{v}$ During the economic boom in the late 1990s the calculation of the cyclical component of the budget for some EU member states resulted to be overestimated, due to the assumption of constant elasticities. This fact misled national fiscal authorities to think that there was room for tax cuts and expenditure increase, which in the following years turned out to be unsustainable.

${ }^{\text {vi }}$ The European Commission showed first steps also toward considering the fact that it is necessary to analyze the behaviour of individual tax bases in order to perform a more precisely estimation of budgetary elasticities as according to the ESCB (ECB) approach (European Commission, 2008).

vii Same data limitation as well as consistency of the results using central government data for Croatia are also emphasized by Benazić (2006), Rukelj (2009) and Vučković (2010). Boije (2004) shows the breakdown of the cyclically adjusted budget balance for Sweden and stresses that "Fiscal policy decisions are usually referred to discretionary changes in revenues or expenditures that affect the central government budget” (p.10) while showing that discretionary fiscal policy in central government budget largely affected the structural budget balance. Moreover, there are other papers about cycilically adjusted budget balances in Finland, Sweden, all Scandinavian countries and Chile, in which the estimation is obtained using central government data (see for instance Brunila and Tujula (1998), Brunila, Hukkinen and Tujula (1999), Braconier and Holden (1999), Marcel et al (2001)).

viii As other methods for estimating potential output, so the Hodrick-Prescott filter has its shortcomings, which have to be noticed. A more detailed discussion on HP filtering and its pro and cons can be found in Guay and St- 
Amant (1997), Ahamuda and Garegnani (1999), Ravn and Uhlig (2002) and Ivanov (2005), as well as the mentioned paper by Bouthevillain et al (2001).

\begin{abstract}
${ }^{\text {ix }}$ Such choice follows empirical practice done by the European Commission and by the ESCB, which is based on the assumption that a business cycle in EU member states on average lasts 8 years. Therefore, the value of the smoothing parameter is set so that compression effects do not exceed 10 percent of the amplitude of cycles of up to 8 years (Bouthevillain et al., 2001, p. 30). As this analysis focuses on the Croatian case it is important to evidence that empirical practice of the HP filter on Croatian data show the use of $\lambda=300$ for quarterly data (see for instance Bačić et al., 2004; Cerovec, 2005 and Švaljek, 2003). This value is based on the assumption that a business cycle in Croatia lasts on average four years. Still, the mentioned researches for the Croatian case were based on the time series reaching the endpoint in year 2004 at most. During the period prior to 2004 business cycles were on average four year long due to high volatility of the economy, but when extending the series up to 2009 (as in this research) it can be noticed that the last business cycle is much longer and therefore increases the average business cycle length. The choice of not using $\lambda=300$ can be also validated by the fact that results obtained using such a smoothing parameter value were on average just 0.001 per cent (and at most 0.4 percent in year 2007) different from those when $\lambda=480$ was used. Being that the fact and in order for the results to be more comparable with those across European countries, $\lambda=480$ is chosen.
\end{abstract}

${ }^{x}$ From independence (year 1990) until 1994, Croatia was facing output declines above 7\% GDP (evidenced real GDP growth rates were: $-7.1 \%$ in 1990, $-21.0 \%$ in $1991,-11.0 \%$ in 1992 and $-8.0 \%$ in 1993).

${ }^{x i}$ In his analysis on the Croatian economic activity from 1999 till 2010, Krznar (2011) shows that the Croatian economy faced a recession in 1999 and 2008, which is same as in this paper. This is important because he used three different methodologies (the simple analysis of quarterly growth rates of GDP, the Bry-Boschanov algorithm and the Markov model) which all yield to same conclusions.

\footnotetext{
${ }^{x i i}$ For a deeper discussion see Petrović (2007), Urban (2006a, 2009a, 2009b).
}

${ }^{\text {xiii }}$ New member states are those that joined the European Union during the 2004- and 2007-enlargement. These enlargements embrace Czech Republic, Cyprus, Estonia, Hungary, Latvia, Lithuania, Malta, Poland, Slovakia and Slovenia in 2004, and Bulgaria and Romania in 2007.

${ }^{\text {xiv }}$ According to the OECD approach the three categories of taxes plus social security contributions and unemployment related expenditure are weighted by their respective shares in GDP (Girouard and Andre, 2005), while according to the EC methodology weights are represented by their respective shares in total revenue.

${ }^{\mathrm{xv}}$ It is important to point out that in the already mentioned research on cyclically adjusted budget balance in Croatia, done by Švaljek, Mervar and Vizek in 2009, the real wage elasticity of income tax per worker resulted to be higher and precisely 1.60, while in this paper it accounts for 1.21 (see Table A2:1) mainly due to the inclusion of the personal income surtax which is levied by local authorities on the basis of the calculated personal income tax liability. Inserting their value (1.60) in the personal income tax elasticity equation (see Appendix 2, equation 1) the output elasticity of income in Croatia would result higher and precisely 0.42 (instead of 0.36, as shown in Table 2 of this work). Still, there would be almost no change in the overall budget elasticity, because the latter is a result of weighted average, where the weight is the share of PIT in total revenues, which in Croatia is very small.

${ }^{\text {xvi }}$ According to van den Noord (2000) and showed in Appendix 2, the measure of progressivity of the personal income tax is proxied by the ratio between the marginal and average tax rates. Nevertheless, it is very important to notice that Urban (2006b) showed how the tax rates schedule in Croatia influence cause just $13 \%$ of the personal income tax progressivity, and that what actually makes it a lot more progressive are the personal allowances (91\% of the progressivity is caused by the latter). In fact, in Croatia the basic personal allowance among tax payers highly differs upon two factors: (1) who and how many persons the tax payer is "sustaining", as for instance children, wife, mother, sister, etc., and (2) where does the tax payer live (different regions have different level of the basic personal allowance). Additionally Urban (2006b) stress that due to this fact, changing the personal income tax to a flat tax rate a very high level of progressivity would still hold.

xvii Although below the EU and OECD average it is important to stress that the estimated elasticities differ from those obtained by Švaljek, Mervar and Vizek (2009) using the ESCB approach. The differences lie in methodological divergence from the two methods used as well as in the smoothing parameter used in HP 
filtering. Their elasticities are higher not only from those obtained in this paper but also from the EU and OECD average. Due to a particularly high elasticity obtained for personal income tax and social security contributions the authors performed also a so-called "non-econometric" approach which resulted in elasticities compared to those in this work.

xviii Counter-cyclical was in 1996, 1998 and 2000, while pro-cyclical in 1997 and 1999.

xix Differences in the estimation may be due to different methodological approaches, lower smoothing parameter for HP filter and shorter time series.

${ }^{x x}$ Dolls et al (2010) prove for the US and 19 EU member states same but lower (-0.10) un-correlation.

${ }^{x x i}$ On July $31^{\text {st }} 2009$ the so-called crisis tax was introduced (levied on net income above 3.000,00 HRK) along with some new fees that increased the cost of sending SMS and MMS in mobile communications.

xxii It is important to mention that from January $1^{\text {st }} 2011$ the Croatian government introduced the so-called Fiscal Responsibility Law (hrv. Zakon o fiskalnoj odgvornosti) which requests fiscal surveillance throughout monitoring the cyclically adjusted budget balance as well.

xxiii From the point of view of the central government's financial situation, a structural surplus can mean a drop in borrowing and in its costs, which makes possible to repay earlier borrowing, decrease new borrowing, leading to a sustained reduction in debt level. 


\section{REFERENCES}

Ahumada, H., and Garegnani, M. L. (1999) Hodrick-Prescott Filter in Practice, Economica(National-University-of-La-Plata); 45(4), pp. 61-76.

Auerbach, A.J. (2002) Is There a Role for Discretionary Fiscal Policy, NBER Working Papers 9306, National Bureau of Economic Research.

Bačić, K., Ahec-Šonje, A., Božić, Lj., Čenić, M., Mervar, A. and Šišinački, J. (2004) Usavršavanje prognostičkog indeksa hrvatskog gospodarstva, research study, Zagreb: Ekonomski institut, Zagreb.

Baunsgaard, T. and Symansky, S.T. (2009) Automatic Fiscal Stabilizers, IMF Staff Position Note SPN/09/23, IMF (available at: http://blog-pfm.imf.org/files/spn09231.pdf)

Blanchard, O.J. (1990) Suggestions for a New Set of Fiscal Indicators, OECD Economics Department Working Papers No. 79, OECD Publishing.

Boije, R. (2004) The General Government Structural Budget Balance, Sveriges Riksbank Economic Review No.1, Sveriges Riksbank.

Bouthevillain, C., Cour-Thimann, P., van der Dool, G., de Cos, P.H., Langenus, G., Mohr, M., Momigliano, S., Tujula, M. (2001) Cyclically Adjusted Budget Balances: an Alternative Approach, Working Paper no. 77, European Central Bank, Frankfurt am Main.

Braconier, H. and Holden, S. (1999) The Public Budget Balance - Fiscal Indicators and Cyclical Sensitivity in the Nordic Countries, National Institute of Economic Research, Stockholm.

Brandner, P., Diebalek, L. and Koehler-Toeglhofer, W. (2007) Budget Balances Decomposed: Tracking Fiscal Policy in Austria, in Larch, M., Martins, J.N., Fiscal Indicators, European Economy Economic Papers, No. 297, European Commission, Brussels, 99-118.

Brown, E.C. (1956) Fiscal Policy in the Thirties: A Reappraisal, American Economic Review 46(5), 857-879.

Brunila, A. and Tujula, M. (1998) Indicators of the cyclically adjusted budget balance, Banca d'Italia workshop on "Indicators of structural budget balance" held in 1998 in Rome, Italy (available http://www.bancaditalia.it/studiricerche/convegni/atti/structural_bud_bal/iii/217250_brunila_and_tujula_2.pdf )

Brunila, A., Hukkinen, J. and Tujula, M. (1999) Indicators of the Cyclically Adjusted Budget Balance, Bank of Finland Discussion papers, n. 1/99.

Buti, M. and van den Noord, P. (2004) Fiscal Policy in EMU: Rules, Discretion and Political Incentives, Economic Papers No. 206, European Commission.

Cerra, V. and Saxena, S.C. (2000) Alternative Methods of Estimating Potential Output and Output Gap: An Application to Sweden, IMF Working paper WP/00/59, IMF (available at: http://www.imf.org/external/pubs/ft/wp/2000/wp0059.pdf).

Cerovac, S. (2005) Novi kompozitni pokazatelji za hrvatsko gospodarstvo: prilog razvoju domaćeg sustava cikličkih pokazatelja, Istraživanja, I-16, Zagreb: Hrvatska narodna banka, http://www.hnb.hr.

Chouraqui, J.C., Hagemann, R.P., Sartor, N. (1990), Indicators of Fiscal Policy: A Reexamination, OECD Department of Economics and Statistics Working Paper No.78, April 1990.

Cimadomo, J. (2005) Has the Stability and Growth Pact Made Fiscal Policy More Procyclical?, CEPII, La lettre du CEPII No. 247.

Croatian Bureau of Statistics' Press Releases (several issues), available at www.dzs.hr visited in August 2010.

Croatian National Bank (2010) - Croatian National Bank Official Website visited in August 2010 - www.hnb.hr. 
Darby, J. and Melitz, J. (2008) Social spending and automatic stabilizers in the OECD, Economic policy 56, 717-746.

Debrun, X. and Kapoor, R. (2010) Fiscal Policy and Macroeconomic Stability: Automatic Stabilizers Work, Always and Everywhere, IMF Working Paper WP/10/11, International Monetary Fund.

Deroose, S., Larch, M. and Schaechter, A. (2008) Constricted, Lame and Pro-cyclical? Fiscal Policy in the Euro Area Revisited, European Commission, DG ECFIN, Economic papers No. 353, December 2008.

Dolls, M., Fuest, C. and Peichl, A. (2009) Automatic Stabilizers and Economic Crisis: US vs. Europe, IZA Discussion Paper Series No. 4310, Institute for the Study on Labour, Bonn (available at http://ftp.iza.org/dp4310.pdf).

Eller, M. (2009) Fiscal Position and Size of Automatic Stabilizers in the CESEE EU Member States - Implications for Discretionary Measures, Focus on European Economic Integration No. 2/09, Oesterreichische Nationalbank, p.78-84.

European Commission (2006) The long-term sustainability of public finances in the European Union, European Economy No. 4/2006, European Commission, Bruxelles.

European Commission (2008) Public Finances in EMU - 2008, European Economy No. 3/2008, European Commission, Bruxelles.

European Commission (2009) Cyclical Adjustment of Budget Balances, DG ECFIN (available at www.ena.lu).

Eurostat (2010) - Official European Statistics Webpage visited in September 2010 http://epp.eurostat.ec.europa.eu.

Gali, J. and Perotti, R. (2003) Fiscal Policy and Monetary Integration in Europe, NBER Working Paper No. 9773.

Giorno, C., Richardson P., Roseveare, D. and van den Noord, P. (1995) Estimating Potential Output, Output Gaps and Structural Budget Balances, OECD Economics Department Working Papers No. 152, OECD Publishing.

Girouard, N. and Andre, C. (2005) Measuring Cyclically-adjusted Budget Balances for OECD Countries, OECD Economics Department Working Papers No. 434, OECD Publishing.

Guay A., and St-Amant, P. (1997) Do the Hodrick-Prescott and Baxter-King Filters Provide a Good Approximation of Business Cycles?, CREFE, Montreal (available at: http://www.unites.uqam.ca/eco/CREFE/cahiers/cah53.pdf).

Hodrick, R. and Prescott, E. (1980) Post-War US Business-Cycles: An Empirical Investigation, Discussion Paper 451, Carnegie-Mellon University Press.

IMF (1986) A Manual on Government Finance Statistics (GFSM 1986), IMF (available at: http://www.imf.org/external/pubs/ft/gfs/manual/1986/eng/index.htm).

IMF (2001) Government Finance Statistics Manual 2001 (GFSM 2001), IMF (available at: http://www.imf.org/external/pubs/ft/gfs/manual/pdf/all.pdf).

IMF (2009) Group of Twenty - Global Economic Policies and Prospects, Note by the Staff of the International Monetary Staff.

Ivanov, L. (2005) Is "the ideal filter" really ideal: the usage of frequency filtering and spurious cycles, South Eastern Europe Journal of Economics, 1 (2005), pp. 79-96.

Kaminsky, G.L., Reinhart, C.M. and Vegh, C.A. (2004) When it Rains, it Pours: Procyclical Capital Flows and Macroeconomic Policies, NBER Working paper 1078 (available at: http://www.nber.org/papers/w10780.pdf).

Krznar, I. (2011) Identifikacija razdoblja recesija i ekspanzija u Hrvatskoj, HNB istraživanja I-32, HNB (available at: http://www.hnb.hr/publikac/istrazivanja/i-032.htm)

Larch, M. and Salto, M. (2003) Fiscal Rules, Inertia and Discretionary Fiscal Policy, economic Papers No.194, European Commission, Brussels. 
Larch, M. and Turrini, A. (2009) The cyclically-adjusted budget balance in EU fiscal policy making: A love at first sight turned into a mature relationship, Economic paper 374, European Commission, Brussels (available at http://ec.europa.eu/economy_finance/publications/publication14644_en.pdf).

Marcel, M., Tokman, M., Valdés, R. and Benavides, P. (2001) Structural Budget Balance: The pillar of the new Chilean fiscal policy rule, Journal Economia Chilena, Volume 4, Issue 3, pp. 15-27.

Marcel, M., Tokman, M., Valdés, R. and Benavides, P. (2003) Structural Budget Balance: Methodology and Estimation for the Chilean Central Government 1987-2001, Ministry of Finance, Santiago, www.dipres.cl.

Ministry of Finance, Republic of Croatia, Statistical informations (several issues), available at ww.mfin.hr, visited in August 2010.

Ministry of Finance, Republic of Croatia, Yearbook (several issues), available at ww.mfin.hr, visited in August 2010.

Mohanty, M. and Scatigna, M. (2002) “Counter-Cyclical Fiscal Policy and Central Banks”, Notes for the central banks' vice-governors meeting on December, 9-10th 2002, Bank for International Settlements.

Petrović, S. (2007) Porez na dohodak i doprinosi za socijalno osiguranje u Hrvatskoj, 19942007, Revija za socijalnu politiku, 14 (3-4), p. 415-426.

Ravn, M. O. and Uhlig, H., (2002) On Adjusting the Hodrick-Prescott Filter for the Frequency of Observations, Review of Economics and Statistics, 84(2), str. 371-376.

Švaljek, S. (2003) Utjecaj fiskalnog stanja na vođenje monetarne politike, in: Analitičke osnove za vođenje monetarne politike tijekom procesa pridruživanja Europskoj uniji, pp. 148-185, Zagreb: Ekonomski institut, Zagreb.

Švaljek, S., Vizek, M. and Mervar, A. (2009) Ciklički prilagođeni proračunski saldo: primjer Hrvatske, Privredna kretanja i ekonomska politika, br. 120, Zagreb, pp. 49-82.

Urban, I. (2006a) Progressivity of personal income tax in Croatia: decomposition of tax base and rate effects, Financial Theory and Practice, 30 (3), p. 207-231.

Urban, I. (2006b) Što porez na dohodak u Hrvatskoj čini progresivnim?, IJF Newsletter Br. 23/2006.

Urban, I. (2009a) Some Characteristics of the 'Crisis Tax' in Croatia, Press Releases No. 11, Institute for Public Finance (available at: http://www.ijf.hr/eng/releases/11.pdf).

Urban, I. (2009b) The tax burden on labour in Croatia [online], Newsletter No. 47, Institute for Public Finance (available at: http://www.ijf.hr/eng/newsletter/47.pdf).

Van den Noord, P. (2000) The Size and Role of Automatic Fiscal Stabilizers in the 1990s and Beyond, OECD Economics Department Working Papers No. 230, OECD Publishing.

Wickens, T.M. (2002) Classification of GFSM 1986 Data to the GFSM 2001 Framework, Government Finance Statistics Manual 2001 Companion Material, IMF (available at: http://www.imf.org/external/pubs/ft/gfs/manual/pdf/class.pdf). 


\section{APPENDIX 1 GOVERNMENT FINANCE STATISTICS}

The GFSM 2001 analytic framework differs considerably from the GFSM 1986 framework (see the Government Finance Statistics Manual 1986 and 2001; IMF (1986, 2001)). Figure A1:1 shows a broad overview of the relationship between GFSM 1986 and GFSM 2001 classification systems.

Figure A1:1 Broad overview of reclassification between GFSM 1986 and GFSM 2001

\section{GFSM 1986}

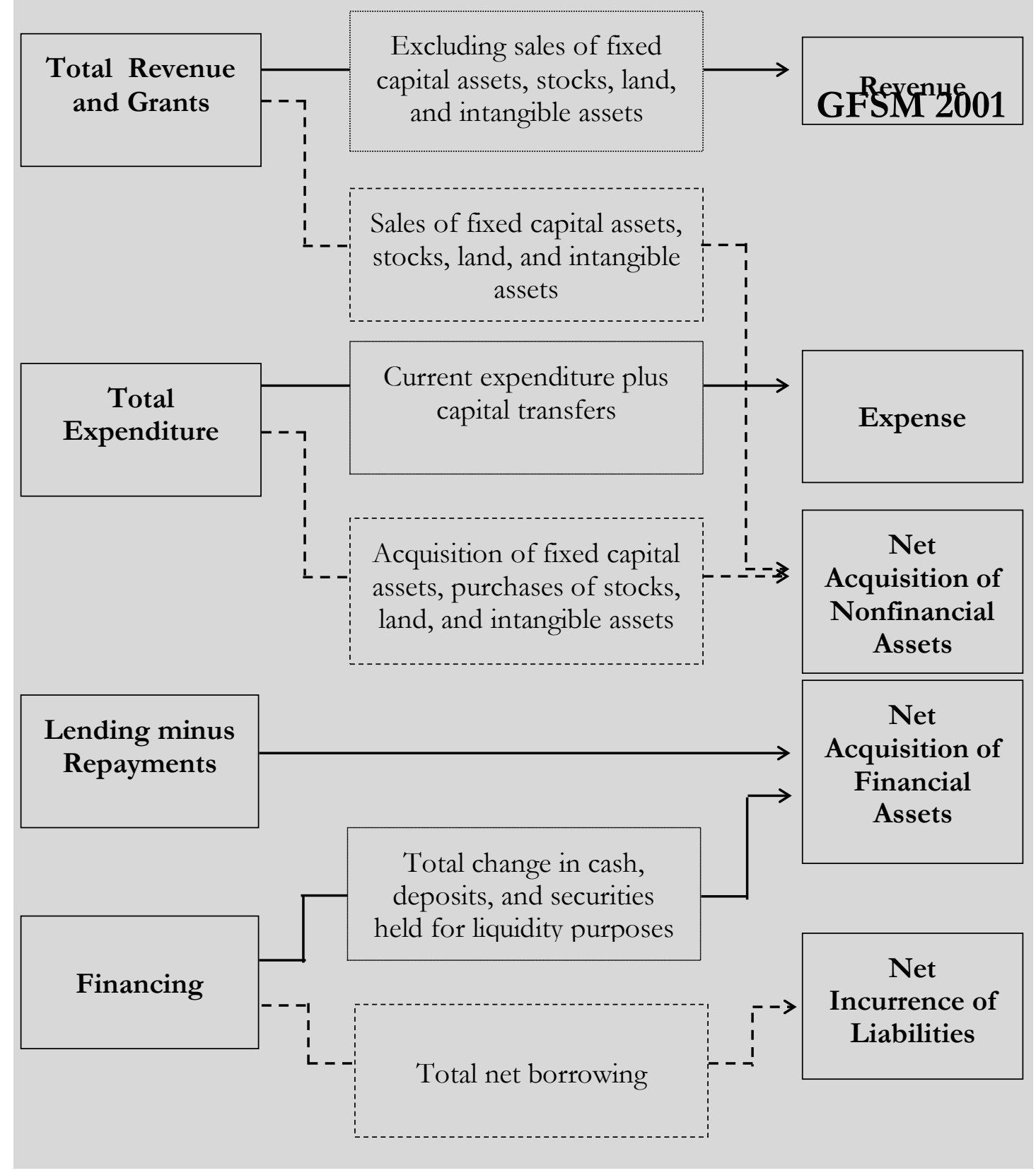

Source: Wickens (2002), IMF (1986), IMF (2001) 


\section{APPENDIX 2 BUDGETARY ITEM’S ELASTICITY -EUROPEAN COMMISSION APPROACH}

All estimations use quarterly data that span the period from 1995:1 to 2009:4, except revenue from VAT which span from 1998:1 to 2009:4. In all cases the OLS estimator was applied to obtain the parameter values, as the chosen methodology suggests. Moreover, equations presented in this Appendix follow van den Noord (2000) and Girourd and Andre (2005). Variables result to be stationary in logs and first differences, except in the case of indirect taxes and consumption, which are stationary in logs only. There is no autocorrelation at the 95\% significance level. Due to the extension of the paper all diagnostic tests are available upon request.

The elasticity of the PIT $\alpha$ can be disaggregated as:

$$
\begin{aligned}
\alpha & =\frac{\partial T}{\partial Y} \cdot \frac{Y}{T}=\frac{\partial[(T / L) \cdot L]}{\partial Y} \cdot \frac{Y}{T}= \\
& -\left(\frac{\partial L}{\partial Y} \cdot \frac{Y}{L}\right) \cdot\left[1+\left(\frac{\partial(T / L)}{\partial w} \cdot \frac{w}{T / L}\right) \cdot\left(\frac{\partial w}{\partial L} \cdot \frac{L}{w}\right)\right]
\end{aligned}
$$

(1a)

(1b) (1c)

where, $Y, T, L, w$, denote respectively output, tax proceeds, employment and wage rate.

The first term (1a) of equation (1) represent the output elasticity of employment. The term (1b) reflects the wage elasticity of personal income tax yield per worker. This elasticity is calculated as a ratio of the marginal and average tax rates for an average taxpayer (Giorno et al, 1995) and captures the progressivity of the tax system. The last term in the elasticity equation (1c) denotes the employment elasticity of wages, which should be interpreted as the Phillips' curve effect on wages.

Table A2:1 Elasticity of PIT in Croatia

\begin{tabular}{cccc}
$\begin{array}{c}\text { Real wage } \\
\text { elasticity of income } \\
\text { tax per worker }\end{array}$ & $\begin{array}{c}\text { Output elasticity of } \\
\text { employment }\end{array}$ & $\begin{array}{c}\text { Employment } \\
\text { elasticity of wages }\end{array}$ & $\begin{array}{c}\text { Output elasticity of } \\
\text { personal income } \\
\text { tax }\end{array}$ \\
\hline A & B & C & D=B(1+AC) \\
\hline 1.21 & 0.16 & 1.03 & 0.36 \\
\hline
\end{tabular}

Source: Author's calculation

The elasticity of the social security contributions follow the same equation (1), just the real wage elasticity of income tax per worker is substituted by the real wage elasticity of social security contributions per worker. This elasticity is set to $1 \%$, in accordance with the proportional rate applied on the wage.

Table A2:2 Elasticity of social security contributions in Croatia

\begin{tabular}{cccc}
\hline $\begin{array}{c}\text { Real wage elasticity of } \\
\text { social security } \\
\text { contributions per } \\
\text { worker }\end{array}$ & $\begin{array}{c}\text { Output elasticity } \\
\text { of employment }\end{array}$ & $\begin{array}{c}\text { Employment } \\
\text { elasticity of wages }\end{array}$ & $\begin{array}{c}\text { Output elasticity } \\
\text { of social security } \\
\text { contributions }\end{array}$ \\
\hline A & B & C & D=B(1+AC) \\
\hline 1.00 & 0.16 & 1.03 & 0.32 \\
\hline
\end{tabular}

Source: Author's calculation 
The elasticity for the CIT can be broken down in two sub-elasticity as:

$$
\begin{aligned}
\alpha & =\frac{\partial T}{\partial Y} \cdot \frac{Y}{T}=\frac{\partial Z}{\partial Y} \cdot \frac{Y}{Z}=\frac{\partial(Y-w L)}{\partial Y} \cdot \frac{Y}{Z}= \\
& =\left[1-\left(1-\frac{Z}{Y}\right) \cdot\left(\frac{\partial L}{\partial Y} \cdot \frac{Y}{L}\right) \cdot\left(1+\frac{\partial w}{\partial L} \cdot \frac{L}{w}\right)\right] \cdot \frac{Y}{Z}
\end{aligned}
$$

where, $Y, T, L, Z, w$, denote respectively output, tax proceeds, employment, corporate income and wage rate.

Because the proportionality assumption implies that the tax elasticity is equal to the elasticity of the tax base (gross corporate profits) to output. The latter elasticity is the function of the elasticity of the wage bill with respect to output, which again, as in the case of PIT elasticity, can be decomposed in the output elasticity of employment (2a) and employment elasticity of wages (2c). For this reason equation (2) can be rewritten as:

$$
\alpha=\left[1-(1-P S) \cdot \varepsilon_{* 2, Y}\right] / P S
$$

where, PS is profit share in GDP and $\varepsilon_{* i, Y}$ the elasticity of the wage bill.

Table A2:3 Elasticity of CIT in Croatia

\begin{tabular}{cccc}
\hline $\begin{array}{c}\text { Gross corporate } \\
\text { profits' share in } \\
\text { GDP }\end{array}$ & $\begin{array}{c}\text { Output } \\
\text { elasticity of } \\
\text { employment }\end{array}$ & $\begin{array}{c}\text { Employment } \\
\text { elasticity of wages }\end{array}$ & $\begin{array}{c}\text { Output elasticity of } \\
\text { corporate income tax }\end{array}$ \\
\hline A & B & C & D=[1-(1-A)B(1+C)]/A \\
\hline $68 \%$ & 0.16 & 1.03 & 1.31 \\
\hline
\end{tabular}

Source: Author's calculation

The elasticity for indirect taxes is based on the assumption that the relevant tax base fluctuates in proportion with private consumption, so:

$\alpha=\frac{\partial C}{\partial Y} \cdot \frac{Y}{C}$

where $\mathrm{C}$ is private consumption and $\mathrm{Y}$ output. Regression estimation showed this elasticity to be $0.5 \%$ of GDP.

Current budgetary expenditures are assumed to fluctuate in proportion to unemployment related expenditures. The elasticity of expenditures can be decomposed as follows:

$$
\begin{aligned}
\beta & =\frac{\partial E}{\partial Y} \cdot \frac{Y}{E}=\left(\frac{U B}{E}\right) \cdot\left(\frac{\partial U B}{\partial Y} \cdot \frac{Y}{U B}\right)= \\
& =\left(\frac{U B}{E}\right) \cdot\left(\frac{\partial U}{\partial Y} \cdot \frac{Y}{U}\right)=\left(\frac{U B}{G}\right) \cdot\left(\frac{\partial L s-\partial L}{\partial L} \cdot \frac{\partial L}{\partial Y} \cdot \frac{Y}{U}\right)= \\
& =-\left(\frac{U B}{E}\right) \cdot\left(\frac{\partial L}{\partial Y} \cdot \frac{Y}{L}\right) \cdot\left\{\left[\frac{1-\left(\frac{\partial L s}{\partial L} \cdot \frac{L}{L s}\right)}{\frac{U}{L s}}\right]-1\right\}
\end{aligned}
$$

where, $U, U B, E, \mathrm{~L}, L s$, denote respectively unemployment, unemployment related expenditure, total government expenditure, employment and labour supply. It is assumed that unemployment related expenditure is strictly proportional to unemployment, whose variations are broken into (a) variations in employment (5a) and (b) variations in the labour force (5b). 
Table A2:4 Elasticity of current primary expenditure

\begin{tabular}{cccccc}
\hline $\begin{array}{c}\text { Output } \\
\text { elasticity } \\
\text { of } \\
\text { employ- } \\
\text { ment }\end{array}$ & $\begin{array}{c}\text { Employ- } \\
\text { ment } \\
\text { elasticity } \\
\text { of labour } \\
\text { supply }\end{array}$ & $\begin{array}{c}\text { Trend } \\
\text { unemplo } \\
\text { y-ment } \\
\text { rate }\end{array}$ & $\begin{array}{c}\text { unemploy-ment } \\
\text { related } \\
\text { expenditure in } \\
\text { total } \\
\text { expenditure }\end{array}$ & $\begin{array}{c}\text { Output elasticity } \\
\text { of unemploy- } \\
\text { ment related } \\
\text { expenditure }\end{array}$ & $\begin{array}{c}\text { Output } \\
\text { elasticity of } \\
\text { current } \\
\text { primary } \\
\text { expenditure }\end{array}$ \\
\hline A & B & C & D & $\begin{array}{c}\mathrm{E}=-\mathrm{A}[(1-\mathrm{B}) / \mathrm{C}- \\
1]\end{array}$ & $\mathrm{F}=\mathrm{DE}$ \\
\hline 0.16 & 0.20 & $17.22 \%$ & $0.85 \%$ & -0.58 & -0.01 \\
\hline
\end{tabular}

Source: Author's calculation

\section{APPENDiX 3 DATA DEFINITION AND SOURCES}

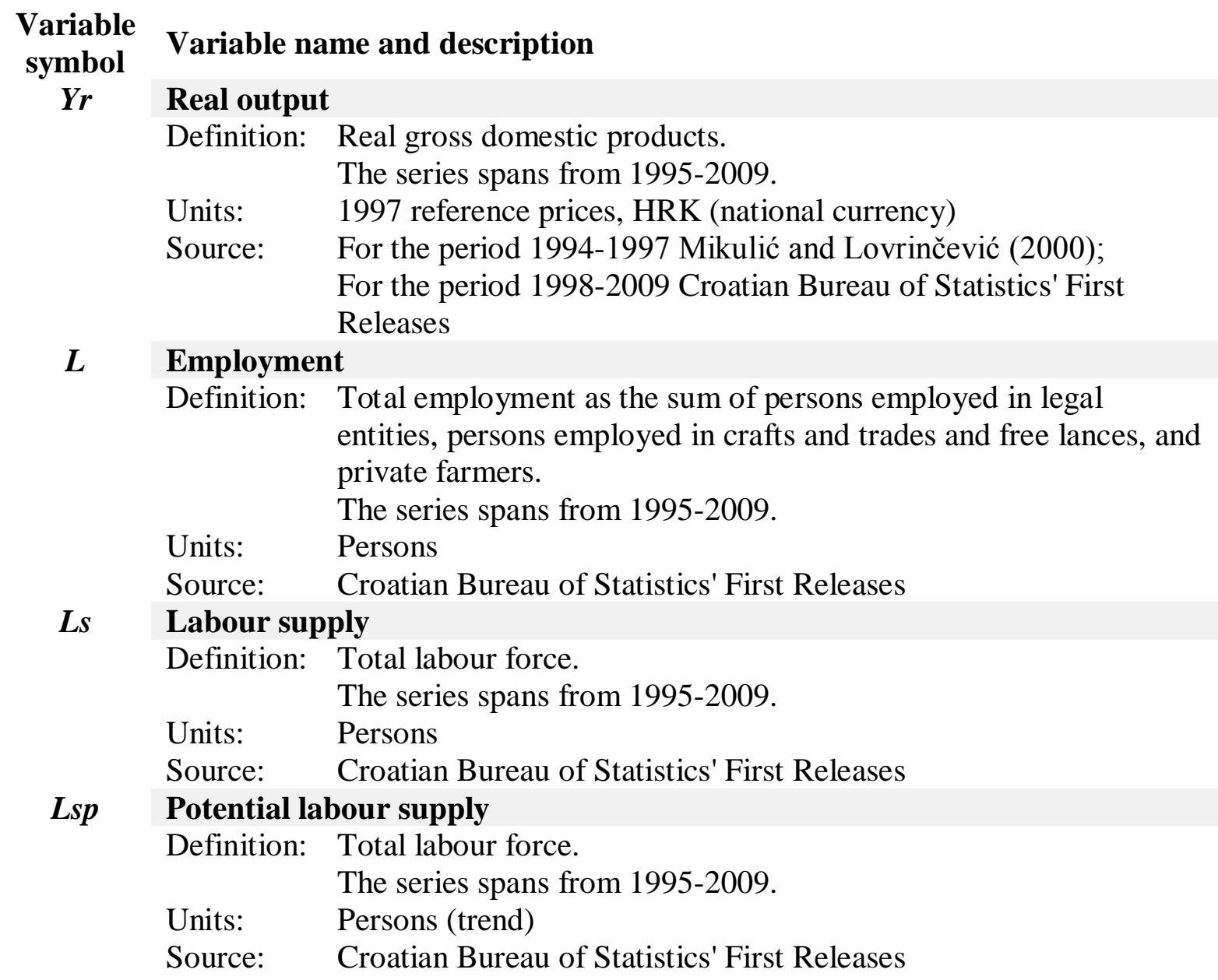


$w L \quad$ Real aggregated wage bill

Definition: The aggregated wage bill is obtained by multiplicating the number of persons in employment by their respective gross wage. This series is built in the following way: (1) for persons employed in legal entities - the number of persons employed in sectors according to the National Classification of Activities is multiplied by the respective average gross wage per sector; (2) for persons employed in crafts and trades and free lances - up to year 1998 the number of persons employed in this group is multiplied by the average gross wage resulted from employment in legal entities because the unavailability of gross wage data for crafts and trades and free lances. For the period after 1998 the number of persons employed in crafts and trades and free lances classified according to the National Classification of Activities is multiplied by their respective gross wage according to the same Classification; (3) private farmers - the number of employed as private farmers is multiplied by the gross wage of those employed in legal entities in the agricultural sector.

The series is deflated by the GDP deflator.

The series spans from 1995-2009.

Units: $\quad$ Current price, HRK (national currency)

Source: Croatian Bureau of Statistics' First Releases

w Real wage

Definition: Real gross wage per employee, i.e. the real aggregated wage bill divided by the employment.

The series spans from 1995-2009.

Units: $\quad$ Current price, HRK (national currency)

Source: $\quad$ Croatian Bureau of Statistics' First Releases

Z Gross corporate profits

Definition: Gross corporate profits are obtained by substracting the real aggregated wage bill from the real gross added value. The series spans from 1997-2009

Units: 1997 reference prices, HRK (national currency)

Source: $\quad$ Croatian Bureau of Statistics' First Releases

CIT Corporate income tax

Definition: Budgetary revenue from corporate income taxation. The series spans from 1995-2009.

Units: $\quad$ Current price, HRK (national currency)

Source: $\quad$ Ministry of Finance, Republic of Croatia

PIT Personal income tax

Definition: Budgetary revenue from personal income taxation.

The series spans from 1995-2009.

Units: $\quad$ Current price, HRK (national currency)

Source: $\quad$ Ministry of Finance, Republic of Croatia 
SSC Social security contributions

Definition: Budgetary revenue from social security contributions.

The series spans from 1995-2009.

Units: $\quad$ Current price, HRK (national currency)

Source: $\quad$ Ministry of Finance, Republic of Croatia

C Personal consumption

Definition: Household final consumption.

The series spans from 1995-2009.

Units: 1997 reference prices, HRK (national currency)

Source: $\quad$ For the period 1994-1997 Mikulić and Lovrinčević (2000); For the period 1998-2009 Croatian Bureau of Statistics' First Releases

VAT Value-added tax

Definition: Budgetary revenue from consumption taxation using VAT.

The series spans from 1998-2009.

Units: $\quad$ Current price, HRK (national currency)

Source: $\quad$ Ministry of Finance, Republic of Croatia

EX Excise duties

Definition: Budgetary revenues from consumption taxation using excises. The series spans from 1995-2009.

Units: $\quad$ Current price, HRK (national currency)

Source: $\quad$ Ministry of Finance, Republic of Croatia

UB Unemployment related benefits

Definition: Unemployment support payment.

The series spans from 1995-2009.

Units: $\quad$ Current price, HRK (national currency)

Source: $\quad$ Ministry of Finance, Republic of Croatia

U Unemployment

Definition: Total unemployment.

The series spans from 1995-2009.

Units: $\quad$ Persons

Source: Croatian Bureau of Statistics' First Releases

E Government expenditures

Definition: Total central government expenditure classified according to GFSM 1986.

The series spans from 1995-2009.

Units: $\quad$ Current price, HRK (national currency)

Source: $\quad$ Statistical Reports of the Ministry of Finance, Republic of Croatia

$\boldsymbol{R}$ Government revenue

Definition: Total central government revenue classified according to GFSM 1986.

The series spans from 1995-2009.

Units: $\quad$ Current price, HRK (national currency)

Source: $\quad$ Statistical Reports of the Ministry of Finance, Republic of Croatia 
$w L \_P I T$ Wage elasticity of personal income tax

Definition: Wage elasticity of personal income tax is the ratio between the marginal personal income tax rate and the average personal income tax rate. The marginal and average tax rates are calculated for income that amounts from half of the average gross wage to the income that amounts to three average gross wages. Marginal and average tax rates are calculated for each quarter independently in order to incorporate the numerous changes in the personal income tax legislation (changes in personal allowance, tax brackets, tax rates).

The series spans from 1995-2009.

Units: $\quad$ Index

Source: Author's calculation according to Croatian Bureau of Statistics' data on wages and Personal income tax Legislation.

$w L \_S S C$ Wage elasticity of social security contributions

Definition: Wage elasticity of social security contributions is the ratio between the marginal social contribution tax rate and the average social contribution tax rate. The marginal and average tax rates are calculated for income that amounts from half of the average gross wage to triple average gross wages. Marginal and average tax rates are calculated for each quarter independently in order to incorporate the changes in applied social security tax rates. The series spans from 1995-2009.

Units: Index

Source: Author's calculation according to Croatian Bureau of Statistics' data on wages and Social security contribution Legislation.

Note: Data in current prices where deflated using the GDP deflator according to the purpose and requests of estimation. 


\section{DISKRECIJSKE MJERE I AUTOMATSKI STABILIZATORI U HRVATSKOJ FISKALNOJ POLITICI}

\section{SAŽETAK}

U posljednje vrijeme se u javnim raspravama često govori o fiskalnoj politici kao o alatu za stabilizaciju fluktuacija poslovnih ciklusa. Ako vlade tijekom pada tržišta dozvole puni zamah automatskih fiskalnih stabilizatora ali ne uspiju se othrvati izazovu da troše povećane ciklicke prihode tijekom uspona, stabilizatori mogu dovesti do pristranosti prema proračunskim pozicijama. Ovaj rad istražuje u kojoj mjeri neke komponente proračuna hrvatske vlade doprinose uravnoteženju poslovnog ciklusa. Kako bi se automatski stabilizatori razdvojili od diskrecijskih mjera, ovo istraživanje se oslanja na metodologiju Europske Komisije. Rezultati pokazuju da je bilanca strukturnog proračuna u deficitu za 1,74\% BDP-a u periodu od 1995 do 2009. Automatska stabilizacija je u Hrvatskoj relativno slaba i potpomognuta diskrecijskim mjerama, što je u Hrvatskoj dovelo do destabilizacije ekonomske aktivnosti u pro-cikličkom smjeru u više promatranih perioda.

Ključne riječi: fiskalna politika, automatski stabilizatori, diskrecijske mjere, ciklički usklađena proračunska bilanca, Hrvatska 